\title{
ABA pretreatment can limit salinity-induced proteome changes in growing barley sprouts
}

\author{
Ewa Szypulska $^{1} \cdot$ Kamil Jankowski $^{1} \cdot$ Stanisław Weidner $^{1}$
}

Received: 2 July 2016/Revised: 21 July 2017 / Accepted: 24 July 2017/Published online: 1 August 2017

(C) The Author(s) 2017. This article is an open access publication

\begin{abstract}
A proteomic study was conducted on caryopses of barley cv. Stratus (Hordeum vulgare). The caryopses were germinated in darkness at $20^{\circ} \mathrm{C}$, according to one of the three experimental setups: (a) in distilled water for $24 \mathrm{~h}$, followed by $100 \mathrm{mM} \mathrm{NaCl}$ for another $24 \mathrm{~h}$ (salinity stress, SS); (b) in $100 \mu \mathrm{M}$ abscisic acid for $24 \mathrm{~h}$, with rinsing in distilled water to remove residual ABA, followed by $100 \mathrm{mM} \mathrm{NaCl}$ for another $24 \mathrm{~h} \mathrm{(pretreatment} \mathrm{with}$ ABA + salinity stress, ABAS); and (c) only in distilled water, for comparison with the tested samples (control, C). After $48 \mathrm{~h}$, proteomes were extracted from barley sprouts in each treatment, according to the method by Gallardo et al. (2002a, b, modified). Proteins were then separated by 2DE and analyzed by MALDI-TOF/MS (Bruker). Under salinity stress, we observed changes in the pattern of proteins involved in: (a) energy metabolism, (b) one-carbon metabolism, (c) cell wall biogenesis, lignification, and adhesion, (d) response to oxidative stress, desiccation stress, and other defense responses, (e) structure and organization of the cytoskeleton, (f) signal transduction, transcription and translation processing, and $(\mathrm{g})$ protein turnover. Our results revealed that $\mathrm{ABA}$ can alter the response of barley seedlings to salinity stress. In general, ABA pretreatment limited stress-induced proteomic changes. Alterations in energy
\end{abstract}

Communicated by M. Hajduch.

Electronic supplementary material The online version of this article (doi:10.1007/s11738-017-2490-x) contains supplementary material, which is available to authorized users.

\section{Ewa Szypulska}

ewa.fraczek@uwm.edu.pl

1 Department of Biochemistry, Faculty of Biology, University of Warmia and Mazury in Olsztyn, Oczapowskiego 1A, 10-957 Olsztyn-Kortowo, Poland and one-carbon metabolism indicate the importance of ABA in glycolytic/gluconeogenic pathways and the SMM cycle during salinity stress. Other observations demonstrated the role of ABA in hemicellulose, cellulose and lignin biosynthesis, ROS scavenging, actin CK formation, control of PI signaling, chromatin-mediated mechanism of stress tolerance, mRNA stability, and protection against dehydration.

Keywords Abscisic acid - Salinity stress $\cdot$ Proteome $\cdot 2 D-$ PAGE $\cdot$ Barley seedlings

$\begin{array}{ll}\begin{array}{l}\text { Abbreviations } \\ \text { 2D PAGE }\end{array} & \begin{array}{l}\text { Two-dimensional electrophoresis in } \\ \text { polyacrylamide gel } \\ \text { Abscisic acid }\end{array} \\ \text { ACTH } & \text { Adrenocorticotrophic hormone } \\ \text { CHAPS } & \text { 3-[(3-Cholamidopropyl) } \\ \text { dimethylammonio]-1-propanesulfonate } & \text { a-Cyano-4-hydroxycinnamic acid } \\ \text { CHCA } & \text { Cytoskeleton } \\ \text { CK } & \text { Dehydrins } \\ \text { DHN } & \text { 3-Dimethylsulfoniopropionate } \\ \text { DMSP } & \text { Dithiothreitol } \\ \text { DTT } & \text { Deubiquitinating enzymes } \\ \text { DUBs } & \text { Glyceraldehyde-3-phosphate } \\ \text { GAPDH } & \text { dehydrogenase } \\ \text { GPX } & \text { Glutathione peroxidase } \\ \text { GST } & \text { Glutathione } S \text {-transferase } \\ \text { HAC } & \text { Histone acetyltransferase } \\ \text { HATs } & \text { Histone acetyltransferases } \\ \text { HGA } & \text { Homogalacturonan } \\ \text { HMT } & \text { Homocysteine methyltransferase } \\ \text { HSC } & \text { Heat shock protein cognate } \\ \text { HSP } & \text { Heat shock protein } \\ & \end{array}$




$\begin{array}{ll}\text { IEF } & \text { Isoelectrofocusing } \\ \text { JIP60 } & \text { 60 kDa jasmonate-induced protein } \\ \text { LEA proteins } & \text { Late embryogenesis-abundant proteins } \\ \text { MALDI- } & \text { Matrix-assisted laser desorption/ionization } \\ \text { TOF/MS } & \text { time-of-flight/mass spectrometry } \\ \text { MMT } & \text { Methionine methyltransferase } \\ \text { MFs } & \text { Microfilaments } \\ \text { PKC } & \text { Protein kinase C } \\ \text { PMF } & \text { Peptide mass fingerprinting } \\ \text { PMT } & \text { Pectin methyltransferase } \\ \text { ROS } & \text { Reactive oxygen species } \\ \text { SAM } & \text { S-Adenosylmethionine } \\ \text { SMM } & \text { S-Methylmethionine } \\ \text { SHMT } & \text { Serine hydroxymethyltransferase } \\ \text { TFA } & \text { Trifluoroacetic acid } \\ \text { UDPGDH } & \text { UDP-D-glucose dehydrogenase } \\ \text { USPs } & \text { Ubiquitin-specific proteases }\end{array}$

\section{Introduction}

Abscisic acid (ABA) is a hormone that is essential for the growth and development of plants. It is also a key mediator of physiological responses to environmental stressors. Plants have to cope with various abiotic stressors, including drought, cold, freezing, heat, and salinity. Crop productivity is considerably thwarted by salinity stress. An excess of mineral salts in soil could result from intensive bedrock weathering or scant precipitation, which prevents leaching of soluble mineral compounds from soil. In recent years, rapid climate changes, including higher temperatures and lower rainfalls, have exacerbated the problem of soil salinity in Europe. Unskillful fertilization can also cause transient soil salinity which is harmful to emerging plants. Soil salinity is induced by higher concentrations of potassium, magnesium and calcium salts, sulfuric acid, and salts of carbonic acid, which leads to excessive alkalization of the substrate and prevents iron uptake. However, soil salinity (sodicity) is largely determined by sodium chloride $(\mathrm{NaCl})$, a soluble salt. Plants growing in saline environments are exposed to two main stressors: the osmotic effect (1) and salt ions which are accumulated in the cytoplasm (2). Under saline conditions, the osmotic potential of soil water decreases, which induces osmotic stress and a decrease in water uptake by plants. Therefore, salinity stress leads to dehydration of plant cells. This non-specific process is also observed in response to other abiotic stressors, such as drought, freezing, and mechanical damage. By contrast, the concentration of salt ions increases only in salinity stress. Moreover, salinity stress is always accompanied by non-specific, oxidative stress.

$\mathrm{ABA}$ is a plant stress hormone and a major endogenous messenger that induces high salinity responses and activates protective mechanisms against dehydration, toxic ions, and oxidation (Fahad et al. 2015). ABA is largely responsible for activating genes responsible for osmotic adjustment, ion compartmentalization and homeostasis, root hydraulic conductivity, membrane stability, shoot and root growth regulation, inhibition of transpiration rate, and wilting, thus contributing to the maintenance of the water and osmotic balance in plants (Lata and Prasad 2011). The discussed phytohormone regulates stomatal closure, thus minimizing transpiration and loss of water (Wilkinson and Davies 2010). Under abiotic stress, stomatal closure and gene expression which are induced by ABA involve $\mathrm{Ca}^{2+}$ and/or $\mathrm{H}_{2} \mathrm{O}_{2}$ as second messengers (Leung and Giraudat 1998; Chinnusamy et al. 2005; Zhang et al. 2007). The group of salt-responsive genes upregulated by ABA includes genes encoding: (1) dehydrins and late embryogenesis-abundant proteins (e.g., $H V A 1, R A B 18, R D 22$, and $A t A D H)$, (2) vacuolar $\mathrm{H}^{+}$-inorganic pyrophosphatase (HVPI and HVP10), tonoplast $\mathrm{Na}^{+} / \mathrm{H}^{+}$antiporter $(N H X 1)$, the catalytic subunit (subunit $\mathrm{A}$ ) of vacuolar $\mathrm{H}^{+}$-ATPase (HvVHA-A), and $\gamma$-tonoplast intrinsic protein-1 (TIP1), (3) mitogen-activated protein kinases (e.g., MAPK4 and OsMAPK5), germin-like protein-1 (GLPl), radical-scavenging antioxidant enzymes, including catalase (CAT), superoxide dismutase (SOD), glutathione reductase (GR), and ascorbate peroxidase (APX), and (4) enzymes that participate in the biosynthesis of osmoprotectants, such as proline and trehalose (Shi and Zhu 2002; Jiang and Zhang 2003; Chinnusamy et al. 2005; Fukuda and Tanaka 2006; Gomez et al. 2010; Keskin et al. 2010; Bakht et al. 2012; Sripinyowanich et al. 2013; Iqbal et al. 2014). Halophytes are plants that tolerate salt, whereas glycophytes such as wheat, rice, barley, soybeans, and potatoes are sensitive to saline conditions. Despite the above, barley is relatively resistant to saline environments (Mahmood 2011).

This study set out to determine the effect of salt stress on changes in the proteome of barley sprouts in an early growth stage. Abscisic acid (ABA) mediates the responses and/or adaptive changes to external stressors in the environment, therefore, the responses of ABA-pretreated barley sprouts to salinity stress were also monitored.

\section{Materials and methods}

\section{Plant material and treatment conditions}

The experiments were conducted on caryopses of barley cv. Stratus (Hordeum vulgare) supplied by the Plant Cultivation Station in Strzelce. Seeds were surface disinfected in $0.5 \%$ sodium hypochlorite for $20 \mathrm{~min}$ and washed with sterilized water. Twenty intact grains were placed on two layers of Whatman paper No. 1 (Whatman, Midstone, 
Kent, UK) in a Petri dish $(\varnothing 9 \mathrm{~cm})$ and germinated in the dark at $20{ }^{\circ} \mathrm{C}$ under different conditions. Caryopses were germinated in distilled water for $24 \mathrm{~h}$ and immersed in $100 \mathrm{mM} \mathrm{NaCl}$ for another $24 \mathrm{~h}$ (salinity stress, SS). The remaining seeds were incubated in $100 \mu \mathrm{M}$ abscisic acid for the first $24 \mathrm{~h}$, rinsed with distilled water to remove residual $\mathrm{ABA}$, and immersed in $100 \mathrm{mM} \mathrm{NaCl}$ for another day (ABA pretreatment + salinity stress, ABAS). Seeds germinated in distilled water for $48 \mathrm{~h}$ were the control (C). The examined material was composed of barley sprouts with a coleoptile emerged and a leaf at the tip. In agricultural practice, the above could be indicative of the germination phase, whereas the growth of a seedling starts with the emergence of the first leaf through the coleoptile and its unfolding. The phenotypes of the analyzed barley sprouts grown under different conditions are shown in Fig. 1.

\section{Determination of sprout length, fresh and dry weight content}

The length (coleoptiles, roots), fresh and dry weight of sprouts were determined in approximately 100 plants from at least three independent biological replicates $(n=3)$ of each sample (C, SS, and ABAS). Sprouts were separated from caryopses, surface drained on filter paper, measured, and weighed. To estimate dry weight content, sprouts were additionally dried at $85{ }^{\circ} \mathrm{C}$ for $48 \mathrm{~h}$ and weighed again. Root length was estimated for the longest root. The data were analyzed using Duncan's test (Statistica 12) and expressed as mean \pm SD. Differences in the length, fresh and dry weight of SS and C samples, and ABAS and SS samples were considered statistically significant at $p \leq 0.01$.

\section{Proteome extraction and $2 \mathrm{D}$ gel electrophoresis}

Proteomes were extracted from the sprouts according to the method described by Gallardo et al. (2002a, b, modified). Young plants were isolated from 100 caryopses in each treatment and powdered in liquid nitrogen. The powdered tissue of each sample was suspended in chilled lysate buffer ( $10 \mu \mathrm{l}$ per $1 \mathrm{mg}$ of calculated DW) containing $7.5 \mathrm{M}$ urea, $2.2 \mathrm{M}$ thiourea, $63 \mathrm{mM}$ CHAPS, $0.25 \%$ Triton X-100 (Bio-Rad), $5 \mathrm{mM}$ Trizma base, $21 \mathrm{mM}$ Trizma hydrochloride, $1.1 \%$ ampholytes $(\mathrm{pH}$ 3-10), 60 U/ml DNase I, 72 lg/ml RNase A (5.8 Kunitz units/ml), $14 \%$ protease inhibitors (Cocktail complete mini, Roche), and $8 \mathrm{mM}$ DTT (Bio-Rad). Each sample was stirred, shaken on ice for $45 \mathrm{~min}$ and centrifuged several times at $12,000 \times g$ for $10 \mathrm{~min}$ to obtain clear supernatant. The protein extract was purified using the $2 \mathrm{D}$ Clean-Up Kit (GE Healthcare). Protein concentration was measured at $280 \mathrm{~nm}$ using a NanoDrop 1000 spectrophotometer (Thermo Scientific). $600 \mu \mathrm{g}$ of the protein sample was solubilized in rehydration buffer (7 M urea, $2 \mathrm{M}$ thiourea, 2\% CHAPS, 0.5\% ampholytes ( $\mathrm{pH} 3-10$ ) (Amersham), $10 \mathrm{mM}$ DTT, and $0.002 \%$ bromophenol blue) to a total volume $450 \mu \mathrm{l}$. The mixture was loaded onto a $24 \mathrm{~cm}$ Immobiline DryStrip Gel strip with a linear pH gradient of 3-10 (GE Healthcare). IEF was performed in the Ettan IPGphor 3 system (GE Healthcare) according to the manufacturer's instructions. Immediately prior to the second-dimensional run, the strip (containing separated proteins) was equilibrated in a glass tube in an equilibration buffer containing $6 \mathrm{M}$ urea, $75 \mathrm{mM}$ Tris$\mathrm{HCl}$ (pH 6.8), 30\% glycerol, and $26 \mathrm{mM}$ DTT (in the first step) or $220 \mathrm{mM}$ iodoacetamide (in the second step) for 15 min each. After equilibration, the strip was transferred to $12.5 \%$ SDS-PAGE gel $(1 \mathrm{~mm})$ and sealed with $10 \%$ agarose solubilized in an electrode buffer containing $25 \mathrm{mM}$ Trizma base, $195 \mathrm{mM}$ glycine, and 0.1\% SDS (Laemmli 1970). Electrophoresis was carried in the EttanDalt Six electrophoresis unit (GE Healthcare) using the Laemmli buffer system, first at $2 \mathrm{~W} / \mathrm{gel}$ for $0.5 \mathrm{~h}$ and then at $17 \mathrm{~W} / \mathrm{gel}$ for the next $3 \mathrm{~h}$. Low Molecular Mass Standards (Bio-Rad) were used to estimate the molecular masses of proteins.
Fig. 1 Phenotypes of 2-day-old barley sprouts isolated from caryopses germinating under different conditions: control (C), salinity stress (SS), and ABA pretreatment (ABAS). A detailed description of germination conditions can be found in the text

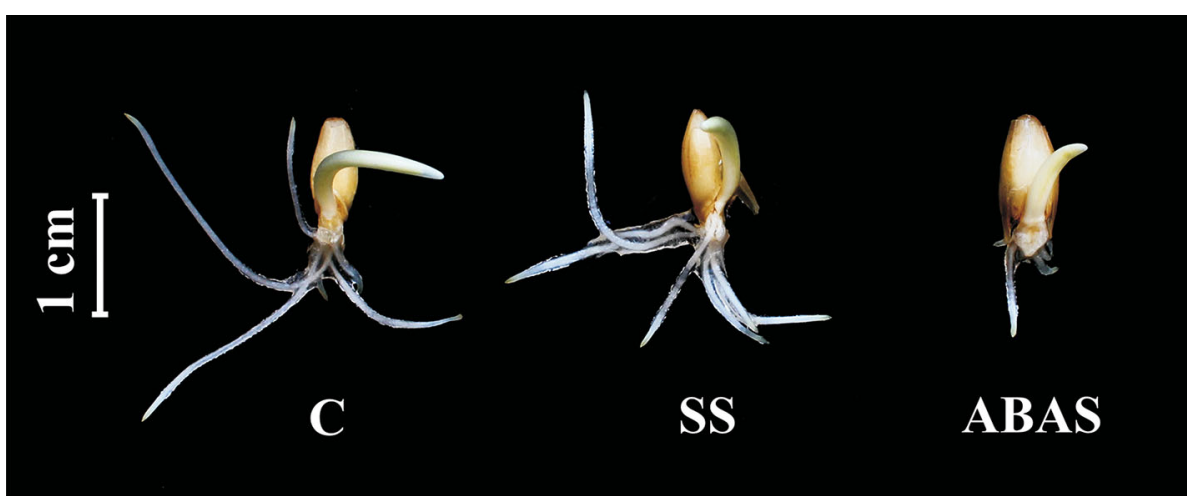




\section{Image and data analysis}

After 2D-PAGE, the gel was stained with Coomassie Brilliant Blue G-250 according to Neuhoff et al. (1988) and scanned in an Image Scanner using the Labscan 3.0 software (GE Healthcare). Three images representing three independent biological replicates for each treatment $(\mathrm{C}, \mathrm{SS}$, and ABAS) were grouped and analyzed in the ImageMaster 2D Platinum 6.0 program. After spot detection, the quantitative determination of spot intensity, including data normalization before principal component analysis (Wibig 2007), was performed based on the average values of background optical density (OD) and spot intensity on each gel. The spot volumes in SS were compared with those in $\mathrm{C}$, and the spot volumes in ABAS were compared with those in SS. Proteins exhibiting at least 1.5-fold reproducible changes in abundance between the compared samples were subjected to statistical analysis using Duncan's parametric test $(p \leq 0.01)$. Proteins whose abundance changed significantly were excised from the gels manually and identified by mass spectrometry.

\section{Protein identification}

The spots which were cut out from the gels were washed and destained with $25 \mathrm{mM}$ ammonium bicarbonate in $50 \%$ ethanol for $1 \mathrm{~h}$ at $37{ }^{\circ} \mathrm{C}$. Before in-gel digestion, proteins were reduced with $10 \mathrm{mM}$ DTT in $25 \mathrm{mM}$ ammonium bicarbonate for $30^{\prime}$ at $60^{\circ} \mathrm{C}$, and alkylated with $10 \mathrm{mM}$ iodoacetamide in $25 \mathrm{mM}$ ammonium bicarbonate for $45^{\prime}$ at $37^{\circ} \mathrm{C}$ in the dark. Proteins were dried in a vacuum centrifuge and digested using sequencing grade trypsin solution (Promega, Madison, USA) containing $10 \mathrm{ng} / \mu \mathrm{l}$ trypsin in $25 \mathrm{mM}$ ammonium bicarbonate. Digestion was carried out at $37{ }^{\circ} \mathrm{C}$ overnight. After in-gel digestion, gels were washed three times with $0.1 \%$ TFA in $50 \%$ acetonitrile to collect protein peptides. After the extraction of peptide fragments from the gel, samples were desalted and cleaned with Zip-Tip C18 (Millipore) according to the manufacturer's instructions. Tryptic mixed peptides in the amount of $1 \mu \mathrm{l}$ were loaded onto an AnchorChip (Bruker) target plate, one volume of saturated CHCA (Sigma) in 50\% v/v acetonitrile with $0.1 \%$ TFA was added, and the peptides were cocrystallized. The loaded target was analyzed in the MALDI-TOF/MS system (Bruker) equipped with a nitrogen laser and operated in a reflector/delayed extraction mode for MALDI-TOF PMF with the FlexControl software (Bruker). The instrument was calibrated externally with $(\mathrm{M}+\mathrm{H})^{+}$ions of Bradykinin 1, Angiotensin II, Angiotensin I, Substance P, Bombesin, Renin Substrate, ACTH clip 1, ACTH clip 18, and Somatostatin 28 (Peptide Calibration Standard II, Bruker). The MS spectra were searched against the National Center for Biotechnology
Information database (NCBI). The MASCOT search engine (http://www.matrixscience.com) was used for PMF search. Database queries were carried out using the following parameters: trypsin cleavage, taxonomy of "Viridiplantae (Green Plants)", monoisotopic mass accuracy with $80 \mathrm{ppm}$ tolerance, one missed cleavage site, carbamidomethylation of cysteine as fixed modification, and oxidation of methionine as variable modification. A protein was positively identified based on the following criteria: protein scores higher than 75 and minimum 10\% protein coverage by the matching peptides, including at least three independent peptides with mass deviation of less than $50 \mathrm{ppm}$. Theoretical $\mathrm{pI}$ and MW values were calculated from the identified sequence in NCBInr using the ExPASy tool (http://www.expasy.org).

\section{Results}

\section{Changes in the length, fresh and dry weight of barley sprouts}

The effect of salinity on barley growth and the changes induced by ABA pretreatment were investigated based on differences in the length of coleoptiles and roots, as well as fresh and dry weight of sprouts. The investigated parameters were altered by the applied treatments, both in SS and in ABAS probes (Fig. 2a, b). In SS probes, the length, fresh and dry weight of stressed plants were reduced by around $45 \%$ (both coleoptile and root), 51 and 33\%, respectively. These results indicate that the growth, dry weight accumulation, and hydration of seedling tissue were significantly inhibited under salinity stress. All of the examined parameters were low in SS, but the stressed sprouts had a characteristic morphology. The roots of stressed seedlings had more root hairs than control roots (Fig. 1). The inhibition of seedling growth under ABA pretreatment was manifested by primary root growth (by around 48\%). Despite the above, changes in the length of coleoptiles or dry weight were not observed in the ABAS sample. However, the average fresh weight of sprouts in ABAS was approximately $28 \%$ higher than in SS.

\section{Changes in the proteome under different treatments}

Our results revealed proteomic changes in barley seedlings treated with $\mathrm{NaCl}$, indicating that $\mathrm{ABA}$ pretreatment altered the salinity response. To separate and identify differentially expressed proteins, IEF/SDS-PAGE coupled with MALDI TOF mass spectrometry was performed. In the group of matched spots, the abundance levels ( $\% \mathrm{vol})$ of 52 protein spots were changed under saline conditions. 
Fig. 2 Effect of different treatments on the growth parameters of barley sprouts: a fresh and dry weight and b length of the coleoptile and the root. The results are presented as mean $\pm \mathrm{SD}$ $(n=3)$. Statistically significant differences are marked with different letters
A
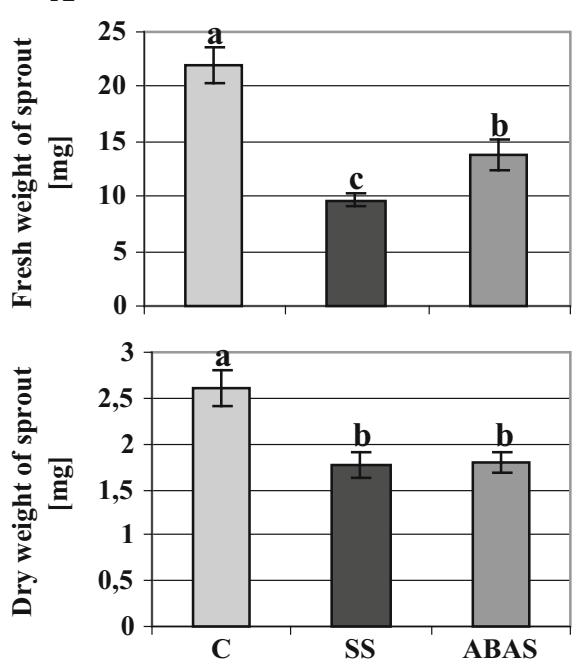

B
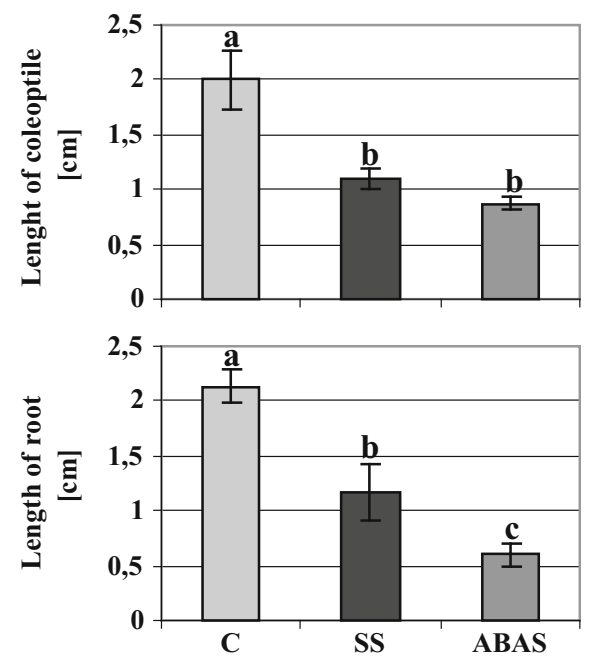

However, 44 of these spots were successfully identified by spectrometric analysis (Fig. 3; Table 1). Based on their function, the identified salt-responsive proteins were classified as proteins involved in: (a) energy metabolism, (b) one-carbon metabolism, (c) cell wall biogenesis, lignification, and adhesion, (d) response to oxidative stress, desiccation stress, and other defense responses, (e) structure and organization of the cytoskeleton, (f) signal transduction, transcription, and translation processing, and (g) protein turnover (Table 1; Fig. 4).

In the group of 44 proteins regulated by salinity, 24 proteins were altered by ABA pretreatment. Exogenously applied ABA minimizes salinity-induced changes. Moreover, the expression of five proteins (spots 13, 14, 15, 26, and 35) in the ABAS probe was silenced to the extent comparable to that noted in the control treatment (Fig. 3; Table 1). The highest percentage of proteins altered by ABA was observed in the group of proteins involved in: (1) biogenesis and lignification of the cell wall and (2) responses to oxidative and desiccation stress. By contrast, ABA did not influence salt-responsive proteins classified as proteins that are involved in other defense responses and protein turnover (Fig. 4).

\section{Discussion}

High salt concentrations inhibit plant growth, development, and survival. Exposure to high salt concentrations influences major life processes in plants (Batool et al. 2014). Our research demonstrated that salinity stress significantly inhibited the growth of barley sprouts. However, the characteristic morphology of roots (with a higher number of root hairs) in stressed plants points to the initiation of protective processes against salinity. The aim of our work was to estimate processes that play a key role in salinity response, including the role of $\mathrm{ABA}$ in salt stress prevention. Our proteomic study revealed salinity-induced changes which can explain the morphological adaptation of sprouts to saline conditions. Incubation in $100 \mu \mathrm{M}$ ABA which inhibits plant growth and development, followed by salinity stress, led to even greater inhibition of root growth, but not the growth or density of root hairs. However, the fresh weight of stressed sprouts preincubated in ABA increased. Jones et al. (1987) demonstrated that the growth of wheat roots was inhibited at ABA concentrations that increased turgor pressure. The above findings suggest that the physiological effect of salt stress was alleviated by ABA pretreatment, mainly by the regulation of the water balance in analyzed barley sprouts. In our study, ABA pretreatment limited stress-induced changes in the barley proteome. Our independent research (data not shown) demonstrated that the treatment of barley caryopses with $100 \mu \mathrm{M}$ ABA induced proteomic changes similar to those caused by salinity, excluding the JIP protein. The observed reduction in the salt-responsive proteome could indicate that $\mathrm{ABA}$ pretreatment plays a role in the acquisition of tolerance to salinity stress. The metabolic functions of proteins affected by both salt and ABA are discussed below.

\section{Energy metabolism}

Under $\mathrm{NaCl}$ stress, plants decrease their metabolic rates to conserve energy and limit ROS production (Möller 2001; Golldack et al. 2014). Two enzymes involved in energy metabolism were downregulated: putative cytochrome c oxidase subunit II PS17 (spot 4) and ATP synthase beta 

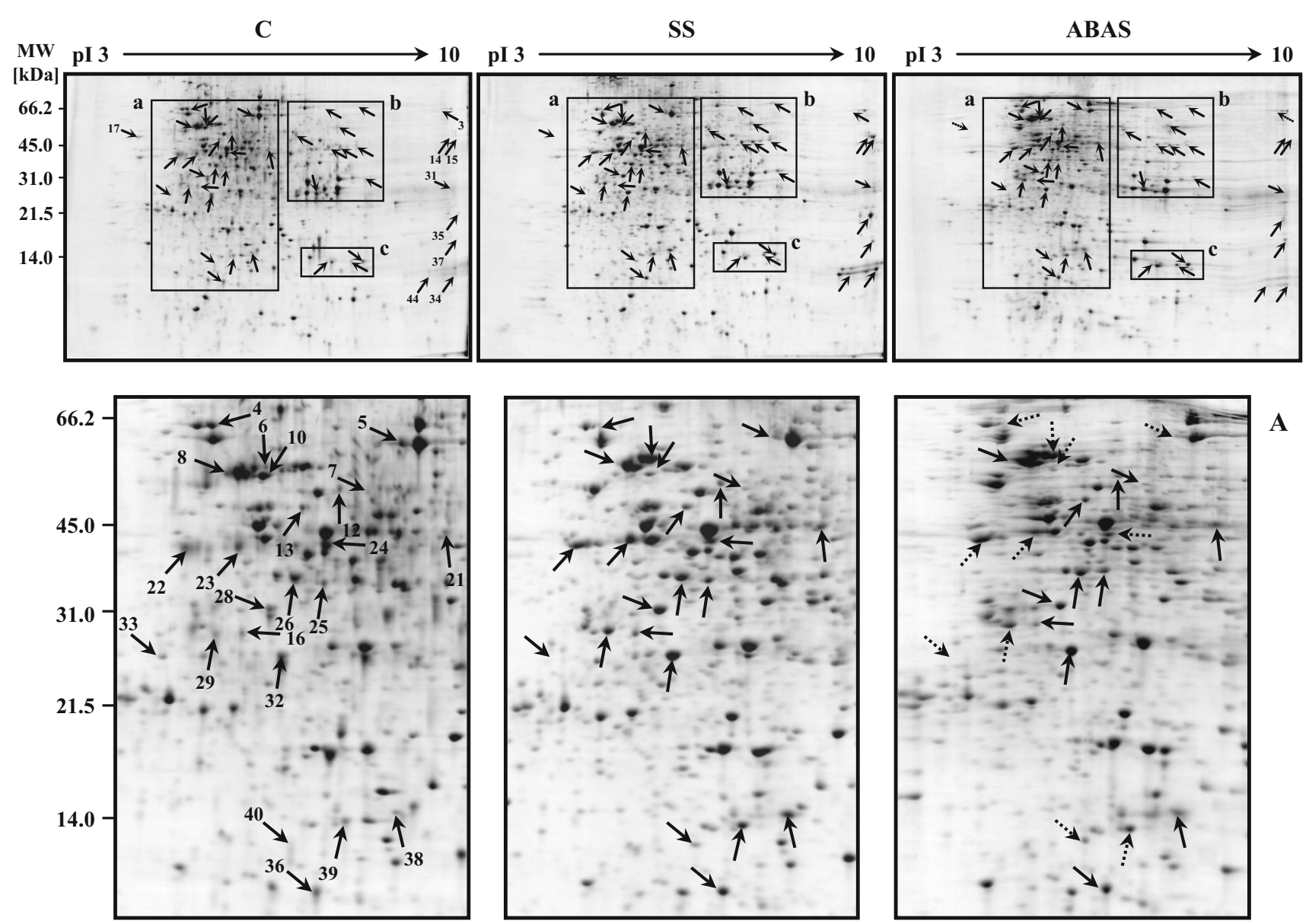

A
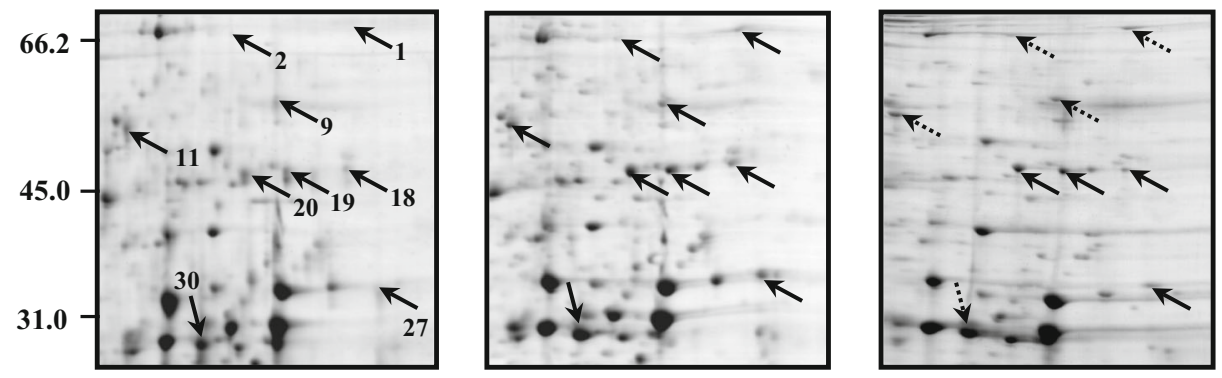

B
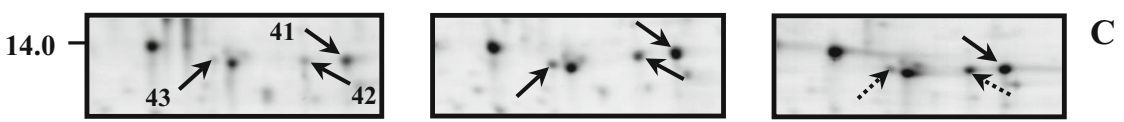

Fig. 3 2DE profiles of proteins from barley sprouts grown under control conditions (C), salt stress conditions (SS), and pretreated with ABA before exposure to salt stress (ABAS). Proteins were separated from each sample in the amount of $600 \mu \mathrm{g}$ by $2 \mathrm{DE}$ and visualized by CBB G-250 staining. They were separated in $\mathrm{pH} 3-10(24 \mathrm{~cm}$, linear $)$ in the first

subunit (spot 10). Cytochrome c oxidase is a terminal enzyme in the mitochondrial respiratory chain, whereas the ATP synthase beta subunit is a mitochondrial protontransporting ATP synthase complex. The downregulation of these proteins could result from the disruptive influence of salinity stress on membranes. dimension and $12.5 \%$ SDS-PAGE in the second dimension. Significantly altered protein spots ( $p \leq 0.01$ ), whose volume $\%$ changed more than 1.5 fold, are marked with arrows (unchanged spots in ABAS are marked with dotted arrows). Altered spots were analyzed by MALDI-TOF/MS. The list of the identified proteins is shown in Table 1

However, not all proteins involved in catabolism were downregulated. For example, we observed the upregulation of the cytosolic enzyme glyceraldehyde-3-phosphate dehydrogenase (GAPDH) (spot 25) which plays a major role in glycolytic and gluconeogenic pathways. GAPDH catalyzes the reversible oxidation and phosphorylation of 
Table 1 Salt stress-responsive proteins from barley seedlings (SS) and the effect of ABA pretreatment on changes in salt response (ABAS)

\begin{tabular}{llllllll}
\hline $\begin{array}{l}\text { Spot } \\
\text { No }\end{array}$ & Protein name & Species & Accession & & Mw (kDa)/pI & & $\begin{array}{l}\text { Peptides/ } \\
\text { Coverage } \\
(\%)\end{array}$ \\
\hline
\end{tabular}

Energy metabolism

$4 \quad$ Putative cytochrome c oxidase subunit II PS17

10 ATP synthase beta subunit, EC 3.6.3.14

25 Glyceraldehyde-3-phosphate dehydrogenase 1, cytosolic, EC 1.2.1.12

One-carbon metabolism, methylation processes

$5 \quad$ Methionine synthase, EC 2.1.1.13

19 Serine hydroxymethyltransferase (SHMT), EC 2.1.2.1

24 S-adenosylmethionine synthase 1 (AdoMet synthase 1), EC 2.5.1.6

28 Homocysteine S-methyltransferase 2, EC 2.1.1.10

P. strobus
T. aestivum
H. vulgare

P84733

$64.19 / 4.70$

1.71/9.31

Q41534

$54.27 / 4.98$

P26517

$36.35 / 5.38$

$83.10 / 7.40)$

$59.25 / 5.56$

$36.51 / 6.67$

$2 / 90$

$12 / 30$

9/32

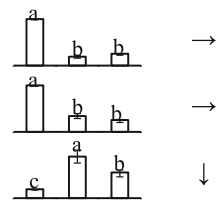

Cell wall biogenesis and adhesion, lignin accumulation

2 Probable methyltransferase PMT10, EC 2.1.1.-

O. sativa

Q8H636

$69.62 / 7.82$

H. vulgare

Q6BCT3

$62.20 / 5.87$

T. monococcum

A6XMY5

47.08/7.46

H. vulgare

P50299

$39.91 / 5.40$

Q9FUM9

33.37/5.00

$68.44 / 7.86$

$84.51 / 5.67$

$56.12 / 8.18$

$42.84 / 5.49$

mays

A. thaliana

Q94KE1

$67.58 / 7.20$

$74.45 / 6.27$

Q8S7R8

$52.309 / 5.47$

$53.43 / 6.32$

rhamnosyltransferase, EC 2.4.1.

o. sativa

H. vulgare

Q40082

51.21/4.6853

$53.61 / 5.31$

G. $\max$

Q96558

45.86/6.18

$52.94 / 5.74$

(UDPGDH 1), EC 1.1.1.22

H. vulgare

Q02126

27.02/9.61

$34.89 / 9.19$ EC 3.2.1.39

Structure and organization of the cytoskeleton

\begin{tabular}{|c|c|}
\hline 23 & Tubulin alfa 1 chain \\
\hline 26 & Actin-58 \\
\hline 36 & $\begin{array}{l}\text { Putative formin-like protein } 15 b \\
\text { (AtFH15b) }\end{array}$ \\
\hline & Profilin1 \\
\hline
\end{tabular}

H. vulgare
S. tuberosum
A. thaliana

Q43473

$41.05 / 4.85$

$49.60 / 4.95$

P30167

$36.35 / 5.21$

41.79/5.46

P0C5K3

11.03/5.49

39.47/6.37

P52184

$13.98 / 5.22$

$14.30 / 5.04$

Signal transduction, transcription and translation processing

$7 \quad 60 \mathrm{kDa}$ jasmonate-induced protein (rRNA N-glycosidase), EC 3.2.2.22

H. vulgare
H. vulgare
H. vulgare
O. sativa
A. thaliana
H. vulgare

Q00531

$58.87 / 5.83$

$60.36 / 6.54$

Q40034

$49.36 / 9.54$

49.14/9.15

Q40041

$48.33 / 4.00$

$47.36 / 4.48$

Q5VNH3

$42.25 / 4.57$

$34.97 / 6.08$

Q9FYH1

26.18/5.15

155.77/8.16

P29305

$25.56 / 4.48$

$29.35 / 4.83$

$19 / 31$

$12 / 20$

$6 / 15$

11/19

4/13

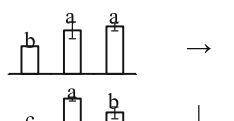

33 14-3-3-like protein A (14-3-3A)

Protein turnover

3 Ubiquitin carboxyl-terminal hydrolase 25 (AtUBP 25), EC 3.4.19.12
Q9FPs2
$64.19 / 9.28$

$73.29 / 9.21$

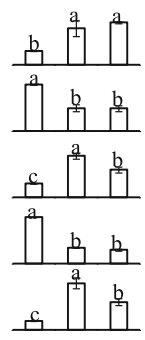


Table 1 continued

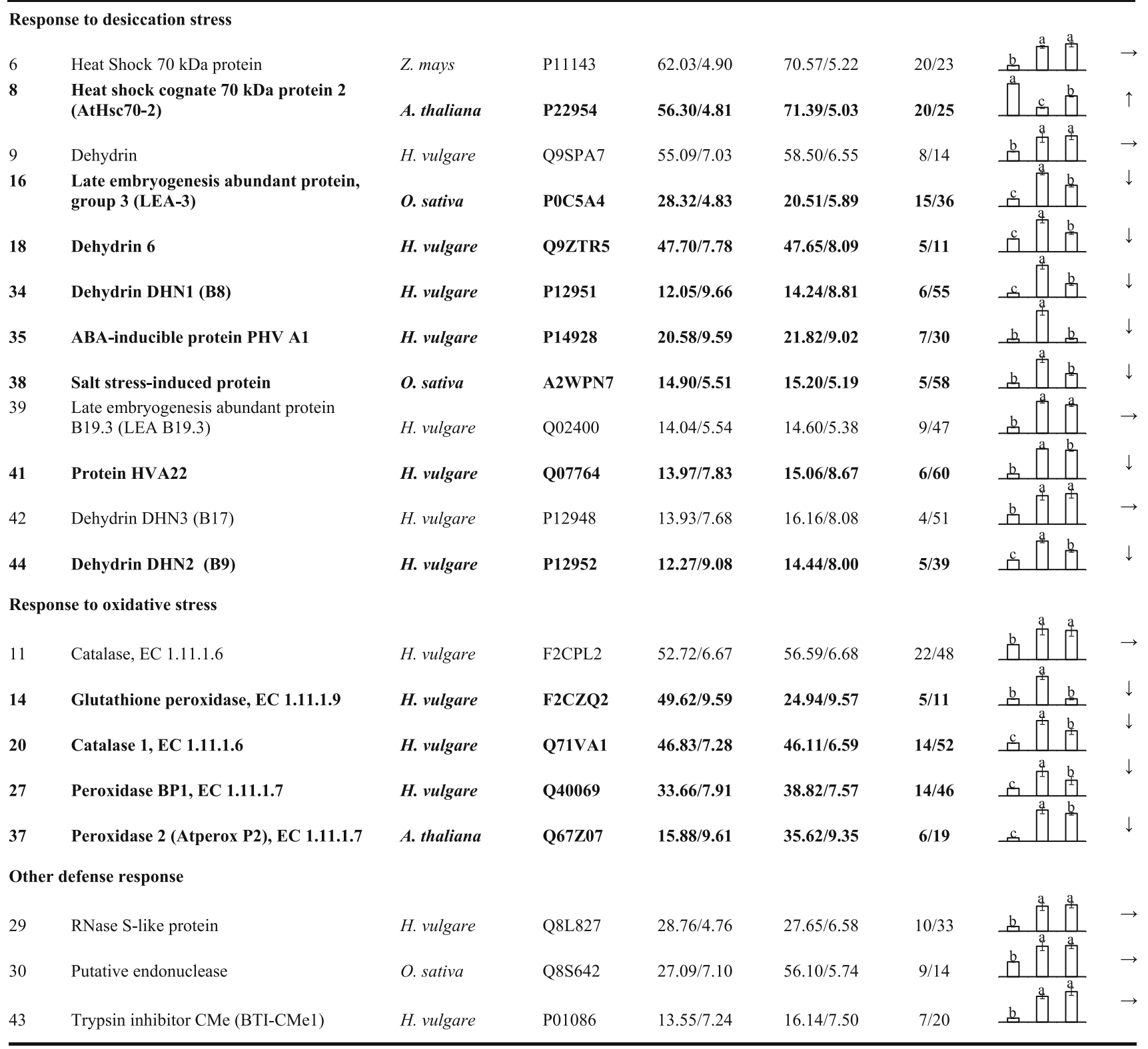

The proteins changed by ABA by more than 1.5-fold at the significance level of $p \leq 0.01$ are marked in bold letters. Arrows $\downarrow \uparrow$ indicate downregulation or upregulation induced by ABA, respectively. Different letters denote statistically significant differences (in the charts). Spot numbers correspond to the spots in Fig. 3

glyceraldehyde 3-phosphate into 3-phospho-D-glyceroyl phosphate. This enzyme is essential for the maintenance of cellular ATP levels and carbohydrate metabolism. GAPDH is synthesized in roots during anoxic conditions, and it belongs to the group of anaerobic polypeptides (Manjunath and Sachs 1997). It appears that GAPDH responds to NAD:NADH and ATP:ADP ratios in the cell to accommodate the cell's specific requirements (Velasco et al. 1994). In addition to its catalytic role, GAPDH is also involved in responses to various abiotic stressors in plants
(Yang Zhai 2017). Under stress, GAPDH plays a pivotal role in redox signaling by interacting with F-actin. Cytosolic GAPDH also interacts with the plasma membrane-associated phospholipase $\mathrm{D}$ (PLD $\delta$ ) in $\mathrm{H}_{2} \mathrm{O}_{2}$-mediated signal transduction. Genetic ablation of PLD $\delta$ impeded stomatal response to abscisic acid and hydrogen peroxide, placing PLD $\delta$ downstream of $\mathrm{H}_{2} \mathrm{O}_{2}$ in mediating ABA-induced stomatal closure (Guo et al. 2012). In our study, GAPDH was the only energy metabolism enzyme to be affected by ABA treatment. 


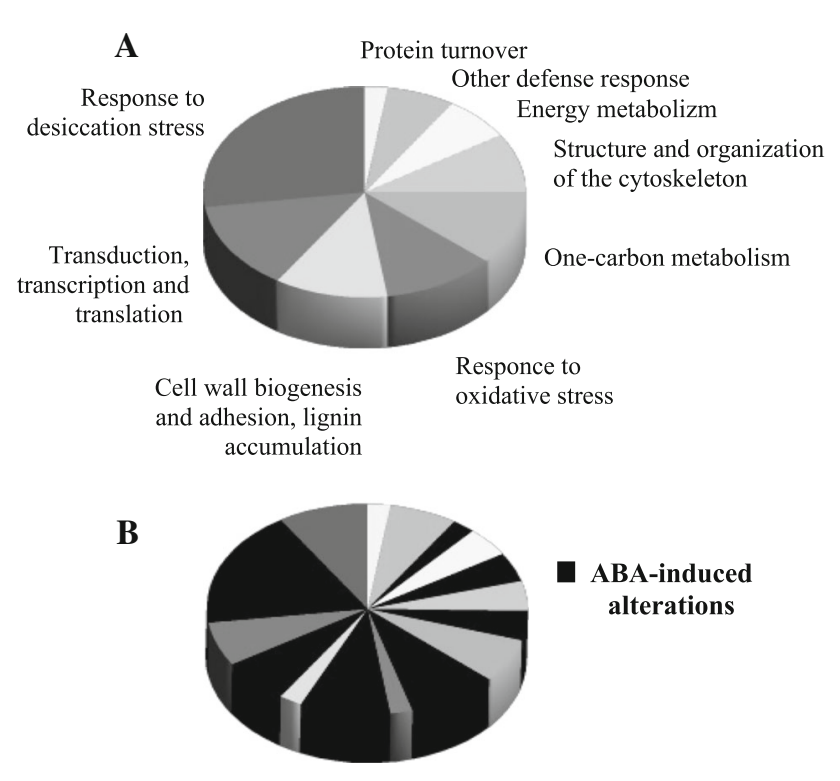

Fig. 4 Percentage of a identified proteins with various metabolic functions in the salinity stress response and $\mathbf{b}$ ABA-regulated proteins in each functional group

\section{One-carbon metabolism}

Methionine (Met) is metabolized in two ways: by (1) the activated methyl cycle or (2) the $S$-methylmethionine (SMM) cycle in one-carbon (C1) metabolism. In the first metabolic process, Met is transformed to $S$-adenosylmethionine (SAM) which participates in the synthesis of selected metabolites, such as glycine betaine, methylated polyols, and polyamines. Glycine betaine and polyols are osmoprotectants which are accumulated in response to water/salinity stress (Bohnert and Jensen 1996; Fujiwara et al. 2010). Polyamines participate in various processes at the cellular level, including DNA replication, transcription, translation, cell proliferation, modulation of enzymatic activity, membrane stability, cation-anion balance in cells, and wall lignification (Gill and Tuteja 2010; Ogawa and Mitsuya 2012).

In the second metabolic process, Met is converted to $S$ methylmethionine in the SMM cycle. SMM is synthesized when a methyl group is transferred from $S$-adenosylmethionine (SAM) to methionine (Met) in a reaction mediated by methionine methyltransferase (MMT), and it is reconverted to Met with homocysteine (Hcy) in a reaction catalyzed by homocysteine methyltransferase (HMT). Ranocha et al. (2001) suggested that the SMM cycle uses half of the synthesized SAM (1) to inhibit the accumulation of SAM. However, SMM is converted to 3-dimethylsulfoniopropionate (DMSP), a compatible solute in selected salt-tolerant plants (Hanson et al. 1994).

In our work, salinity induced the downregulation of two enzymes involved in the activated methyl cycle- methionine synthase (spot 5) and $S$-adenosylmethionine synthase (spot 24), and the upregulation of homocysteine $S$-methyltransferase (spot 28) involved in MMT. In this group of enzymes, only HMT was altered by ABA. This observation revealed changes in one-carbon metabolism, and it emphasized the importance of SMM in salinity response and ABA action. Our findings differ from the results reported in other studies, where the activated methyl cycle played the main role in responses to ABA and salt treatment. Espartero et al. (1994) suggested that SAM genes are responsive to salt stress and that ABA could participate in the upregulation of $S A M$ transcripts.

Serine hydroxymethyltransferase (SHMT), an enzyme that catalyzes the reversible conversion of serine and tetrahydrofolate (THF) to glycine and $N^{5}, N^{10}$-methylene$\mathrm{THF}$, is also involved in the pathway for the interconversion of C-1 compounds. We identified SHMT (spot 19) as a salinity-upregulated protein which was also altered by ABA treatment. We also observed the upregulation of dehydration-responsive protein (spot 1), a predicted protein with $S$-adenosylmethionine-dependent activity. The increase in both proteins in the analyzed tissue emphasizes the significance of methylation processes during salinity stress. Less is known about the direct influence of ABA on SHMT, but Verslues et al. (2007) and Kaur et al. (2009) suggested links between sensitivity to ABA and glycolate metabolism, in particular the activity of peroxisomal glu:glyoxylate aminotransferase (GGT). GGT converts glycolate to glycine, the substrate for SHMT. GGT is essential for ABA-induced accumulation of proline and gene expression, and accumulation of $\mathrm{ABA}$ under exposure to stress and pretreatment with $\mathrm{ABA}$. The results of this study validate the assumption that hydrogen peroxide participates in ABA signaling in proline accumulation.

\section{Cell wall biogenesis, lignification, and adhesion}

The cell walls of monocots, including wheat and barley, are composed of a cellulosic network embedded in a matrix of hemicellulose fibers and pectin polysaccharides. The major polysaccharides include glucuronoarabinoxylans and $(1,3 ; 1,4)-\beta$-D-glucans, whereas the levels of glucomannans, xyloglucans, and pectic polysaccharides are relatively low (Farrokhi et al. 2006).

In our study, selected enzymes responsible for wall synthesis were upregulated under salinity stress. We identified two enzymes involved in hemicellulose synthesis: UDP-D-glucose dehydrogenase (spot 21) and xylose isomerase (spot 13). UDP-D-glucose dehydrogenase (UDPGDH) oxidizes UDP-D-glucose (UDP-Glc) to UDPD-glucuronate (UDP-GlcA), the precursor of UDP-D-xylose and UDP-L-arabinose, and the main cell wall polysaccharide precursors. Xylose isomerase catalyzes the synthesis 
of D-xylose from D-xylulose, a precursor of xyloglucan, and hemicellulose.

Another detected enzyme, glucan endo-1-3- $\beta$-glucosidase GIII (spot 31), could play a role in the synthesis of cellulose. Several authors have demonstrated that hydrolytic enzymes are involved in the reorganization of newly synthesized cellulose chains (Szyjanowicz et al. 2004; Farrokhi et al. 2006). Moreover, the key quantitative trait locus (QTL) associated with the content of $(1,3 ; 1,4)-\beta$-Dglucan in barley grain co-segregates with the gene encoding $(1,3 ; 1,4)$ - $\beta$-D-glucanase (Han et al. 1995).

We also identified pectin methyltransferase, probable methyltransferase PMT10 (spot 2) which could control cell wall adhesion by incorporating methyl groups into pectin in their synthesis site (Vannier et al. 1992; Goubet and Mohnen 1999). Pectic polysaccharides such as homogalacturonan (HGA) are produced in the Golgi apparatus. HGA comprises a linear chain of $\alpha$-1,4-linked D-galacturonic acid (GalA) that undergoes different methyl esterification reactions at C6 (Bacic et al. 1988). The degree of pectin methyl esterification is a key determinant of pectin's adhesive properties (Krupková et al. 2007).

We also observed the upregulation of three enzymes involved in lignin biosynthesis: putative anthocyanidin-3glucoside rhamnosyltransferase (spot 12) and two peroxidases-peroxidase BP1 (spot 27) and peroxidase 2 (spot 37).

In the walls of grass cells, lignin is a polymer composed of phenylpropanoid monolignol units: hydroxycinnamic, ferulic, and $p$-coumaric acids. Ferulic acid and, partly, $p$ coumaric acid are esterified to arabinose molecules of arabinoxylans. Arabinoxylan polymers are also crosslinked through diferulates (Jung and Deetz 1993).

Oxidative stress caused by pathogenic infections, wounding, and other environmental stressors leads to oxidative burst and the release of ROS. Peroxidases catalyze the reduction of $\mathrm{H}_{2} \mathrm{O}_{2}$ by relying on cell wall molecules as substrates such as lignin precursors, phenolic compounds, or auxin, which leads to polymerization reactions, including suberization, lignification, and cell wall protein cross-linking (Kristensen et al. 1999; Passardi et al. 2004a, b). An increase in peroxidase levels could suggest that the cell wall is undergoing modification to reduce the influx of ions under saline conditions. Moreover, lignification is intensified by putative anthocyanidin-3glucoside rhamnosyltransferase which is involved in the biosynthesis of flavonoids, stilbene and lignin. Peroxidases play an important role in the metabolism of apoplastic ROS, and they contribute to root growth and development. Hydrogen peroxide appears to be involved in root growth restriction and root hair formation (Dunand et al. 2007). In their oxygenated form (oxyperoxidases), peroxidases can increase $\mathrm{H}_{2} \mathrm{O}_{2}$ levels in the zone of differentiation in roots.
The catalytic versatility of peroxidases can explain the morphological changes observed in barley roots in our study. Hydrogen peroxide could inhibit root growth and stimulate root hair formation under salt stress. The observed significant inhibition of root growth, accompanied by rapid formation of root hairs, indicates that $\mathrm{ABA}$ pretreatment enhances the mechanisms of resistance to environmental stress.

Our results suggest that the maintenance of cell wall architecture is crucial under stress and that ABA plays an important role in this process. The only protein that was not affected by abscisic acid was probable methyltransferase PMT10 (spot 2). These findings emphasize the importance of ABA in cellulose and hemicellulose synthesis and in lignification processes which increase the thickness of cell walls. Park et al. (2011) suggested a possible connection between the involvement of MYB52 genes in ABA response and cell wall biosynthesis. Other authors noted that ABA inhibits seed germination by preventing the loosening and expansion of cell walls (Gimeno-Gilles et al. 2009). Our results suggest that ABA induces cell wall thickening by increasing the biosynthesis of cell wall components, which could restrict elongation and enhance protective mechanisms against stress.

\section{Response to oxidative stress}

Other enzymes that catalyze ROS scavenging, including catalase (spot 11,20) and glutathione peroxidase (spot 14), were also identified in this study. Roxas et al. (2000) reported that overexpression of glutathione $S$-transferase with glutathione peroxidase activity (GST/GPX) in transgenic plants promoted the growth of seedlings under exposure to various stressors. They demonstrated that seedlings expressing GST/GPX (GST+) were characterized by a high growth rate under exposure to low temperatures and saline stress, whereas the growth of control seedlings was stunted under the same conditions. In other studies, transgenic GST+ seedlings were significantly more abundant in oxidized glutathione (GSSG) under exposure to stress in comparison with wild-type seedlings (Roxas et al. 1997). High levels of GSSG could point to intensified scavenging activity of GPX-dependent peroxide in seedlings. The above could prevent cellular damage, promote metabolic activity, and stimulate growth in seedlings (Roxas et al. 2000). According to Miao et al. (2006), GPX3 plays a dual role: first, as a scavenger of $\mathrm{H}_{2} \mathrm{O}_{2}$, and second, as a transducer in $\mathrm{ABA}$ and $\mathrm{H}_{2} \mathrm{O}_{2}$ signaling pathways, where it regulates stomatal movement during drought.

In plant cells, the activity of ABA could be related to oxidative stress. This phytohormone could stimulate the 
production of $\mathrm{H}_{2} \mathrm{O}_{2}$ (Zhang et al. 2001; Jiang and Zhang 2001, 2003) and induce the expression of selected antioxidant genes encoding, for example, catalase (CAT) and peroxidase (POX) (Guan et al. 2000; Jiang and Zhang 2003; Agarwal et al. 2005). Low doses of ABA $(10-100 \mu \mathrm{M})$ triggered an antioxidant defense mechanism to prevent oxidative damage to membrane lipids and proteins (Jiang and Zhang 2001). A minor, ABA-induced increase in $\mathrm{H}_{2} \mathrm{O}_{2}$ levels could be required to build stress tolerance and enhance survival in plants exposed to environmental stressors.

\section{Structure and organization of the cytoskeleton}

We identified two cytoskeletal proteins: tubulin alpha-1 chain (spot 23) and actin-58 (spot 26), as well as proteins that affect cytoskeleton (CK) organization: profilin1 (spot 40) and putative formin-like protein 15b (AtFH15b) (spot 36). All proteins were upregulated under saline conditions. Tubulin is a building block of the cytoskeleton, and it is involved in the intracellular transport of organelles, including chromosomes and mitotic spindles. The first group of compounds that are targeted by oxidative stress includes tubulin (Apraiz et al. 2006; Wu et al. 2013). In animal cells, $\beta$-tubulin can promote phosphorylation during microtubule formation, and it protects the cytoskeleton against oxidative stress (Howard and Hyman 2003). The cytoskeleton is also composed of microfilaments (MFs) which could play a role during salt stress. According to Zhao et al. (2013), stress signaling relies on the interactions between microfilaments and $\mathrm{Ca}^{2+}$ in plants. In bacteria, the actin cytoskeleton controls immune cell signaling and the production of cytokines and reactive $\mathrm{O}^{2-}$ (Aktories et al. 2011).

Profilin is a ubiquitous protein which binds to actin and modifies cytoskeletal structure by polymerizing or depolymerizing actin filaments. It also participates in plant cell responses to internal and external signals (Fatehi et al. 2012). Profilin is involved in signaling pathways, which promotes rapid formation of actin filaments (Ridley et al. 2003; Lindberg et al. 2008; Yu 2008). Actin polymerization also involves formins which belong to a different family of multimodular proteins (Carlier and Pantaloni 2007). Formins associate with the fast-growing end of actin filaments and incorporate actin from profilin:actin structures (Romero et al. 2007; Sarmiento et al. 2008; Yu 2008).

In the present study, ABA affected two cytoskeletal proteins: actin and putative formin-like protein, which suggests that $\mathrm{ABA}$ influences the organization of actin filaments. The cytoskeleton is involved in signaling, and the potential significance of ABA-induced actin reorganization is described below.

\section{Signal transduction, transcription, and translation processing}

The signal transduction pathway starts with signal perception by different receptors, such as ion channels. In plant cells, the transient influx of $\mathrm{Ca}^{2+}$ ions is one of the earliest responses to salinity stress. The initial increase in cytosolic $\mathrm{Ca}^{2+}$ is followed by the generation of secondary signaling molecules such as inositol phosphates or reactive oxygen species. In turn, secondary signaling molecules can provoke the release of other receptor-mediated $\mathrm{Ca}^{2+}$. The influx of $\mathrm{Ca}^{2+}$ ions initiates the protein phosphorylation cascade, followed by the activation of proteins that are directly involved in cellular protection or the regulation of stress-responsive genes (Xiong et al. 2002).

In our study, we identified four proteins that are directly or implicitly involved in PI signaling: EF1 $\alpha$ (spot 15), calreticulin (spot 17), putative calcium-binding protein annexin 6 (spot 22), and 14-3-3-like protein A (spot 33), which were responsive to salinity. EF1 $\alpha$ was also altered by ABA pretreatment.

$\mathrm{EF} 1 \alpha$ is a common protein elongation factor, but there is evidence to suggest that it also plays an important role in controlling phosphatidylinositol signaling, which leads to F-actin remodeling (Amiri et al. 2007) and increases the amount of CK surrounding ER and Lys content in maize endosperm (Azama et al. 2003). eEF1 $\alpha$ has the ability to bind and bundle F-actin. During PI signaling, PI is converted via PIP and $\mathrm{PIP}_{2}$ forms to $\mathrm{IP}_{3}$, which triggers the release of $\mathrm{Ca}^{2+}$ from cellular stores. Actin MFs could regulate the activity of $\mathrm{Ca}^{2+}$ channels (Wang et al. 2011). It has been reported that PIK-A49, an eEF1A-like protein isolated from carrots, binds and activates carrot phosphatidylinositol-4 kinase (PI4K) in response to an increase in cytosolic calcium. In turn, PI4K catalyzes the biosynthesis of phosphatidylinositol-4 phosphate (PI4P) (Yang and Boss 1994). According to Choi et al. (2008), PIP (PI3P and PI4P) participates in the reorganization of ABA-induced actin filament and stomatal closing in guard cells. They suggested that ABA increases the content of PI3P and PI4P which are involved in the generation of ROS. This triggers an influx of $\mathrm{Ca}^{2+}$, the activation of actin-binding proteins (ABPs), such as profilin, and facilitates the reorganization of actin.

In the presence of calcium, membrane binding proteins, annexins, interact with membrane phospholipids and activate PI signaling. Two proteins were identified in this study: putative calcium-binding protein annexin 6 (spot 22) and 14-3-3A (spot 33) as positive and negative regulators of protein kinase $\mathrm{C}$ (PKC), respectively. Annexin A6 acts as a scaffold for recruiting $\mathrm{PKC} \alpha$ to the plasma membrane, without its phosphorylation (Lizarbe et al. 2013). 14.3.3A inhibits PKC and activates $\mathrm{H}^{+}$-ATPase (Chen et al. 1994; 
Chen et al. 2006a, b; Schoonheim et al. 2007). The downregulation of 14.3.3 during salinity stress could result in: (1) reduction of $\mathrm{H}^{+}$-ATPase activity, followed by stomatal closure to prevent water loss and (2) phosphorylation of PKC and activation of $\mathrm{Ca}^{2+}$-ATPase by receptormediated hydrolysis of inositol phospholipids.

The $\mathrm{Ca}^{2+}$-storage protein calreticulin is an ER chaperone protein which is also found in Golgi bodies and plasma membrane. Cytosolic $\mathrm{Ca}^{2+}$ levels increase under salt stress when they are released from calcium storage sources. Typically, calreticulin is activated under stress conditions (Tuteja and Sopory 2008). In our study, salinity reduced calreticulin levels, which can be attributed to the release of free $\mathrm{Ca}^{2+}$.

Our study also demonstrated changes in translation and transcription processing in response to salinity. Histone acetyltransferase HAC2 (spot 32) and $60 \mathrm{kDa}$ jasmonateinduced proteins (spot 7) were upregulated during salinity stress. Both HAC2 and $60 \mathrm{kD}$ JIP were ABA-modulated. Acetylation of histones leads decreases transcriptional activation by: (1) DNA relaxation and (2) changes in the interactions between chromatin and chromatin-associated proteins (Fang et al. 2014). Histone acetyltransferases (HATs) are involved in the chromatin-mediated mechanism of stress tolerance in plants exposed to ABA and salt stress (Chen et al. 2006a, b; Sokol et al. 2007; Zhou et al. 2009). $60 \mathrm{kDa}$ jasmonate-induced protein (JIP60) is a ribosome-inactivating protein (RIP). JIP60 exhibited $\mathrm{N}$-glycosidase activity and hydrolyzed the adenine residue from a conserved loop of 25S rRNA ( $\alpha$-sarcin/ricin loop). The $\alpha$-sarcin/ricin loop binds elongation factors (EFs) to ribosomes. Therefore, any modifications in this fragment of $25 \mathrm{~S}$ rRNA lead to the inactivation of the large ribosomal subunit and cessation of protein synthesis during the elongation step (Dunaeva et al. 1999; Sawasaki et al. 2008). JIP60 also plays a key role in inhibiting cytoplasmic protein synthesis via reversible ribosome dissociation into small and large subunits (Reinbothe et al. 1994; Rustgi et al. 2014). Some authors have suggested that the upregulation of JIP60 during salinity stress inhibits growth (Görschen et al. 1995) and protects plants against stress. Our results confirm the correlation between salinity and higher levels of $60 \mathrm{kDa}$ jasmonate-induced protein. Surprisingly, exogenously applied ABA inhibited the expression of JIP60 (independent experiment, data not shown). Our findings differ from the observation that ABA, similar to jasmonic acid (JA), can induce JIPs (Lehmann et al. 1995). According to some reports, ABA promotes JA accumulation (Fan et al. 2009). Furthermore, the presence of MYC and NAC transcription factors suggests the existence of cross-talk between JA and ABA signaling (Singh and Laxmi 2015). It should also be noted that ABA and JA antagonistically regulate the expression of salt stress- inducible proteins (Moons et al. 1997). In our previous study (Szypulska and Weidner 2016), the following responses were observed in salt-stressed barley sprouts: (1) increase in the content of free cytosolic polysomes resulting from damage to cell membranes and (2) increase in the concentrations of ribosomal units and free monosomes. The results of the present study suggest that the above could be attributed to the action of JIP60. ABA's antagonistic effect on JIP60 expression could explain the inhibition of ribosome dissociation and, consequently, the stabilization of polysomes, which was observed in our previous study.

\section{Response to desiccation stress}

We identified two main groups of proteins involved in responses to desiccation stress: HSP and LEA proteins. These proteins were upregulated mainly under salinity stress, excluding the HSC70-2 protein (spot 8) which was strongly downregulated.

In general, HSP70 chaperones are involved in the folding of newly synthesized protein chains, prevention of aggregation and refolding of proteins denatured by stress, separation of protein aggregates, translocation of proteins across membranes, and disposal of misfolded proteins (Yong et al. 2003; Cazale et al. 2009; Song et al. 2014). The above explains the high levels of $70 \mathrm{kDa}$ HSPs (spot 6) in stress conditions. The negative effect of salinity on HSC70 (heatshock protein cognate) expression is unclear, and it could result from low protein yield under stress (Badowiec et al. 2012). HSC70-2 was the only protein whose expression increased under exposure to abscisic acid. The upregulation of HSC70 protein in response to ABA treatment provides additional evidence that translation processes are more effective in response to ABA treatment.

Late embryogenesis-abundant (LEA) proteins and members of this group, such as RAB (responsive to ABA) proteins, also known as dehydrins (DHN), are thought to be involved in protein repair during water stress. Due to their chaperone-like properties, LEA proteins assist proteins that were denatured or misfolded by water stress in recovering their native conformation (Campbell and Close 1997; Brini et al. 2007). In our study, the following LEA proteins were upregulated due to salinity stress: dehydrin (spot 9), dehydrin 6 (spot 18), group 3 LEA proteins (spot 16), late embryogenesis-abundant protein B19.3 (spot 39), protein HVA22 (spot 41), dehydrin DHN1 (spot 34), dehydrin DHN2 (spot 44) and dehydrin DHN3 (spot 42). In this group, HVA22, dehydrin 6, dehydrin DHN2, and dehydrin DHN3 were altered under ABA pretreatment.

Exposure to salinity stress also increased the levels of ABA-inducible protein PHV A1 (spot 35) and salt stressinduced protein (spot 38 ), both of which were altered by 
ABA. Hong et al. (1988) demonstrated that the amino acid sequence of PHV A1 shares homology with the LEA7 protein in cotton. Claes et al. (1990) observed that the organ-specific response of sa/T (transcripts of salt stressinduced protein) was correlated with the pattern of $\mathrm{Na}^{+}$ accumulation during salt stress.

\section{Protein turnover}

The ubiquitin-proteasome pathway is largely responsible for the degradation of specific cellular proteins during various processes, including exposure to salinity stress (Kornitzer and Ciechanover 2000; Wang et al. 2011;

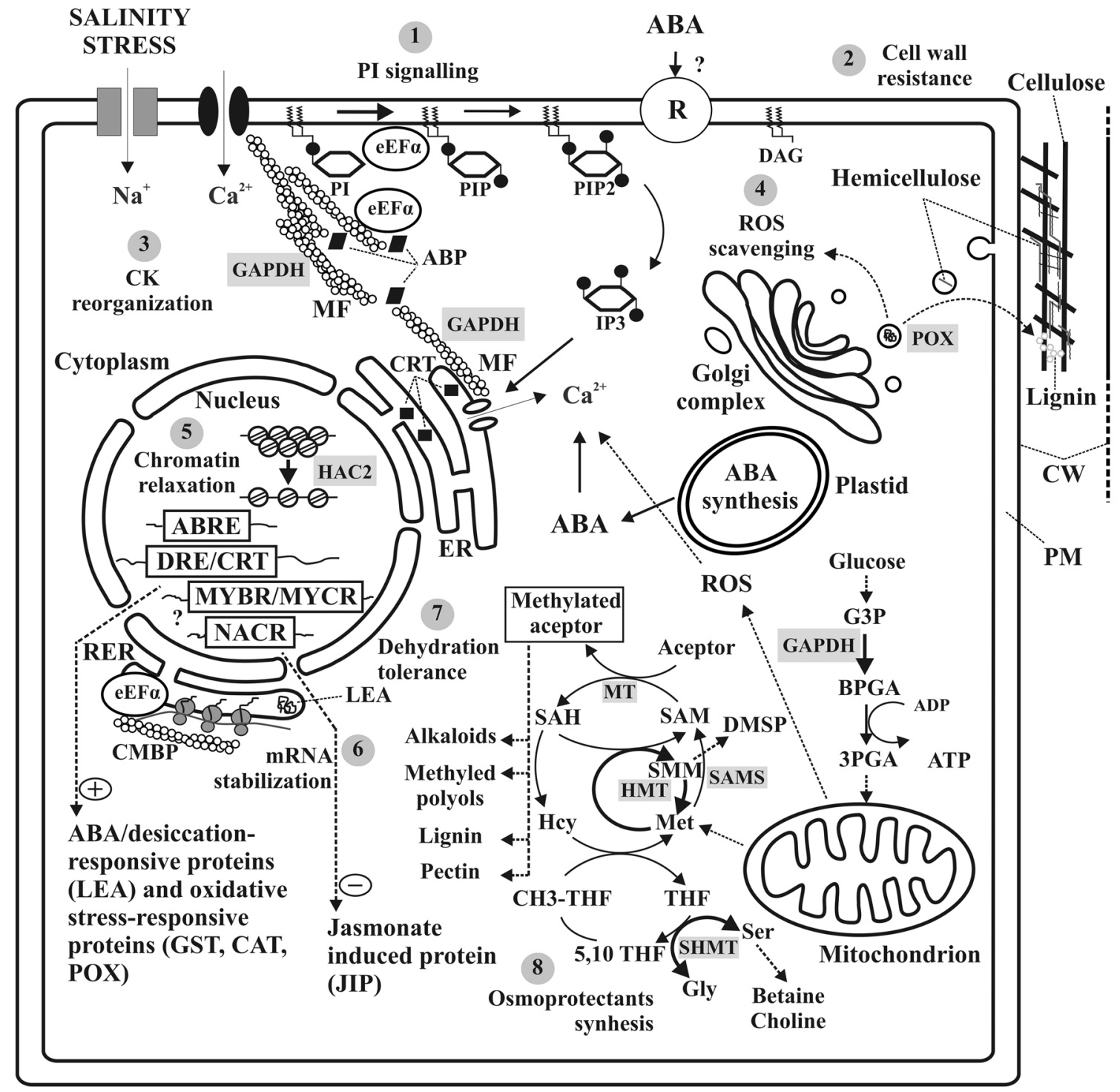

Fig. 5 Hypothetical model of ABA's influence on salt tolerance in higher plants. The role of ABA in salt response may consist in: (1) PI signaling and $\mathrm{Ca}^{2+}$ release due to $\mathrm{EF} 1 \alpha$ regulation and cytoskeletal reorganization, (2) increase in cell wall resistance due to changes in hemicellulose, cellulose, and lignin synthesis, (3) cytoskeleton remodeling due to interactions with $\mathrm{ABP}$ and GAPDH, (4) ROS scavenging by antioxidant enzymes (GST, CAT, and POX), (5) chromatin relaxation due to changes in HAC2, (6) translation regulation due to improved mRNA stabilization, (7) dehydration tolerance, mainly due to synthesis of LEA proteins in RER, and (8) osmoprotectant synthesis (DMSP, betaine). The regulated metabolic pathways are marked with bold arrows. $A B P$ actin-binding protein (e.g., formin), $c i s$-regulatory elements: $A B R E$ ABA-responsive element, $D R E / C R T$ dehydration-responsive element/C-repeat, $M Y B R /$ $M Y C R$ myeloblastosis oncogene/myelocytomatosis oncogene recognition element, NACR non-aggressive challenge responsive element, $C K$ cytoskeleton, $C M B P$ cytoskeleton-membrane-bound polysomes (cytomatrix-bound polysomes), $C R T$ calreticulin, $C W$ cell wall, $D A G$ diacylglycerol, $E R$ endoplasmic reticulum, $M F$ actin microfilament, $P M$ plasma membrane, $R$ potential ABA receptor, and $R E R$ rough endoplasmic reticulum. A detailed description can be found in the text 
Lyzenga and Stone 2012; Zhang et al. 2014). According to Yan et al. (2000), ubiquitin-specific proteases (USPs)) play a host of important roles in the ubiquitin/26S proteasome pathway by: (1) releasing of free ubiquitins from their translation products, (2) recycling of ubiquitin during degradation of the target compound, which involves the removal of ubiquitin from peptide fragments and splitting of multiubiquitin chains, and/or (3) removing ubiquitins from conjugates before the degradation of the target compound. The latter role indicates that USPs prevent target degradation. These deubiquitinating enzymes (DUBs) are a group of ubiquitin-specific thiol proteases which break the bond between the Gly C-terminus of ubiquitin and covalently attached polypeptides (Yan et al. 2000). In our study, ubiquitin-specific protease 25 (spot 3) was upregulated under salinity stress. The described processes explain the role of protease which was identified in this study in response to salinity stress.

\section{Other defense responses}

The following salt-responsive proteins were identified in this study: RNase S-like protein (spot 29), putative endonuclease (spot 30) and trypsin inhibitor CMe (spot 43). All of the above proteins were upregulated in response to salinity and were not modified by ABA pretreatment.

It has been reported that $\mathrm{S}$-like RNase genes are induced in response to various biotic and abiotic factors ( $\mathrm{Ye}$ and Droste 1996; Galiana et al. 1997; Lee et al. 2009; Zheng et al. 2014). Although the amino acid sequence of S-like RNases is closely related to that of S-RNase, it has no RNase activity (Van Damme et al. 2000; Lee et al. 2009). $\mathrm{S}$-like RNases play an important role in phosphate recycling during senescence and are induced by inorganic phosphate starvation, which is associated with the accumulation of anthocyanins (Ticconi et al. 2001; Lee et al. 2009). Salinity stress induces the accumulation of anthocyanins (Borghesi et al. 2011). Pi starvation could also be associated with salinity stress.

During oxidative stress, the influx of ROS can damage DNA structure (Saha et al. 2015). Efficient DNA repair mechanisms remove oxidized bases. For example, endonuclease III (NTH protein) and endonuclease VIII (NEI protein) from Escherichia coli cells excise many oxidized pyrimidines (Laval 1996; Kumari et al. 2009). The observed upregulation of endonuclease (spot 30) could play a role in DNA repair during salinity stress accompanied by oxidative stress.

Specific protease inhibitors are currently being overexpressed in certain transgenic plants to protect them against invaders (Habib and Fazili 2007) rather than to induce stress tolerance. It has been reported that the sequence of the maize $\alpha$-amylase/trypsin inhibitor resembles the sequence of osmotin (Claes et al. 1990), a salt-responsive protein. However, protease inhibitors could inhibit the degradation of storage proteins and stilt the growth of saltstressed seedlings.

\section{Influence of $\mathrm{ABA}$ pretreatment on salinity response-summary}

In general, ABA pretreatment limited stress-induced changes in the proteome. Interestingly, ABA-inducible protein PHV A1 (spot 35) was one of the five strongly downregulated proteins (to the level comparable with that noted in the control treatment). This finding suggests that the influence of $\mathrm{ABA}$ pretreatment on salinity response results from a regulation process, but not downregulation in the strict sense. It implies that ABA plays a major role in plant responses to salinity stress.

The observed changes in GAPDH point to the importance of glycolytic/gluconeogenic pathways in the ABA-modulated salinity response. The regulation of HMT suggests that ABA influences the SMM cycle. The noted changes in the expression of HMT and SHMT indicate that ABA is implicated in the synthesis of osmoprotectants. Other observations demonstrate the important role of ABA in hemicellulose, cellulose, lignin biosynthesis, and ROS scavenging. ABA's influence on cytoskeletal structure and formation was manifested in the reorganization of actin microfilaments (MFs). We allow for the possibility that GAPDH, in addition to formins the proteins classified to ABPs (actin-binding proteins), can take part in this process. The alterations in EF1 $\alpha$ and HAC2 could indicate that ABA participates in the control of PI signaling and chromatin-mediated mechanism of stress tolerance. The number of proteins responsive to desiccation stress was altered by $\mathrm{ABA}$ pretreatment (mainly dehydrins), which suggests that ABA contributes to protection against dehydration. Our previous research revealed that $\mathrm{ABA}$ treatment increases the concentration of cytomatrix-bound polysomes, a fraction of polysomes that are attached to the membrane and the cytoskeleton, mainly actin microfilaments (Szypulska and Weidner 2011). In that study, we suggested the role of cytomatrix-bound polysomes in LEA proteins synthesis. Moreover, our previous study demonstrated that exogenous abscisic acid stabilizes polysomes, which could be attributed to the high concentration of cytomatrix-bound structures (Weidner et al. 2006). The present study demonstrated the role of ABA in JIP regulation, which expands our knowledge of other factors implicated in mRNA stabilization. In the light of our present and previous findings, we have proposed a hypothetical model of ABA's role in the induction of salt tolerance in barley sprouts (Fig. 5). 
Author contribution statement ES: idea, realization, laboratory work, and description of results. KJ: laboratory work. SW: financial support and consultancy.

Open Access This article is distributed under the terms of the Creative Commons Attribution 4.0 International License (http://crea tivecommons.org/licenses/by/4.0/), which permits unrestricted use, distribution, and reproduction in any medium, provided you give appropriate credit to the original author(s) and the source, provide a link to the Creative Commons license, and indicate if changes were made.

\section{References}

Agarwal S, Sairam RK, Srivastava GC, Meena RC (2005) Changes in antioxidant enzymes activity and oxidative stress by abscisic acid and salicylic acid in wheat genotypes. Biol Plant 49(4):541-550

Aktories K, Lang AE, Schwan C, Mannherz HG (2011) Actin as target for modification by bacterial protein toxins. FEBS J 278:4526-4543

Amiri A, Noei F, Jeganathan S, Kulkarni G, Pinke DE, Lee JM (2007) eEF1A2 activates akt and stimulates akt-dependent actin remodeling, invasion and migration. Oncogene 26:3027-3040

Apraiz I, Mi J, Cristobal S (2006) Identification of proteomic signatures of exposure to marine pollutants in mussels (Mytilus edulis). Mol Cell Proteom 5:1274-1285

Azama K, Abe S, Sugimoto H, Davies E (2003) Lysine-containing proteins in maize endosperm: a major contribution from cytoskeleton-associated carbohydrate-metabolizing enzymes. Planta 217:628-638

Bacic A, Harris PJ, Stone BA (1988) Structure and function of plant cell walls. In: Preiss J (ed) The biochemistry of plants. Academic Press, New York, pp 297-371

Badowiec A, Sylwia Świgońska S, Szypulska E, Weidner S (2012) Influence of exogenous abscisic acid on alterations in protein expression in the proteome of Triticosecale seedlings. Acta Physiol Plant 34:2359-2368

Bakht J, Khan MJ, Shafi M, Khan MA, Sharif M (2012) Effect of salinity and aba application on proline production and yield in wheat genotypes. Pak J Bot 44(3):873-878

Batool N, Shahzad A, Ilyas N, Noor T (2014) Plants and salt stress. Int J Agric Crop Sci 7(9):582-589

Bohnert HJ, Jensen RG (1996) Strategies for engineering water-stress tolerance in plants. Trends Biotechnol 14:89-97

Borghesi E, González-Miret ML, Escudero-Gilete ML, Malorgio MLF, Heredia FJ, Meléndez-Martínez AJ (2011) Effects of salinity stress on carotenoids, anthocyanins, and color of diverse tomato genotypes. J Agric Food Chem 59(21):11676-11682

Brini F, Hanin M, Lumbreras V, Irar S, Pagès M, Masmoudi K (2007) Functional characterization of DHN-5, a dehydrin showing a differential phosphorylation pattern in two Tunisian durum wheat (Triticum durum Desf.) varieties with marked differences in salt and drought tolerance. Plant Sci 172:20-28

Campbell SA, Close TJ (1997) Dehydrins: genes, proteins, and associations with phenotypic traits. New Phytol 137:61-74

Carlier MF, Pantaloni D (2007) Control of actin assembly dynamics in cell motility. J Biol Chem 282:23005-23009

Cazale A-C, Clément M, Chiarenza S, Roncato M-A, Pochon N, Creff A, Marin E, Leonhardt N, Noël LD (2009) Altered expression of cytosolic/nuclear HSC70-1 molecular chaperone affects development and abiotic stress tolerance in Arabidopsis thaliana. J Exp Bot 60(9):2653-2664
Chen Z, Fu H, Liu D, Chang P-FL, Narasimhan M, Ferl R, Hasegawa PM, Bressen RA (1994) A NaCI-regulated plant gene encoding a brain protein homolog that activates ADP ribosyltransferase and inhibits protein kinase C. Plant J 6(5):729-740

Chen F, Li Q, Sun L, He Z (2006a) The rice 14-3-3 gene family and its involvement in responses to biotic and abiotic stress. DNA Res 13:53-63

Chen Z, Zhang H, Jablonowski D, Zhou X, Ren X, Hong X, Schaffrath R, Zhu J-K, Gong Z (2006b) Mutations in ABO1/ ELO2, a subunit of holo-elongator, increase abscisic acid sensitivity and drought tolerance in Arabidopsis thaliana. Mol Cell Biol 26(18):6902-6912

Chinnusamy V, Jagendorf A, Zhu J-K (2005) Understanding and improving salt tolerance in plants. Crop Sci 45:437-448

Choi Y, Lee Y, Jeon BW, Staiger CJ, Lee Y (2008) Phosphatidylinositol 3- and 4-phosphate modulate actin filament reorganization in guard cells of day flower. Plant Cell Environ 31(3):366-377

Claes B, Dekeyser R, Villarroel R, Van den Bulcke M, Bauw G, Van Montagu M, Caplan A (1990) Characterization of a rice gene showing organ-specific expression in response to salt stress and drought. Plant Cell 2:19-27

Dunaeva M, Goebel C, Wasternack C, Parthier B, Goerschen E (1999) The jasmonate-induced $60 \mathrm{kDa}$ protein of barley exhibits $\mathrm{N}$-glycosidase activity in vivo. FEBS Lett 452:263-266

Dunand C, Crèvecoeur M, Penel C (2007) Distribution of superoxide and hydrogen peroxide in Arabidopsis root and their influence on root development: possible interaction with peroxidases. New Phytol 174:332-341

Espartero J, Pintor-Toro JA, Pardo JM (1994) Differential accumulation of S-adenosylmethionine synthetase transcripts in response to salt stress. Plant Mol Biol 25(2):217-227

Fahad S, Hussain S, Matloob A, Khan FA, Khaliq A, Saud S, Hassan S, Shan D, Khan F, Ullah N, Faiq M, Khan MR, Tareen AK, Khan A, Ullah A, Ullah N, Huang J (2015) Phytohormones and plant responses to salinity stress: a review. Plant Growth Regul 75(2):391-404

Fan J, Hill L, Crooks C, Doerner P, Lamb C (2009) Abscisic acid has a key role in modulating diverse plant-pathogen interactions. Plant Physiol 150:1750-1761

Fang H, Liu X, Thorn G, Duan J, Tian L (2014) Expression analysis of histone acetyltransferases in rice under drought stress. Biochem Biophys Res Commun 443:400-405

Farrokhi N, Burton RA, Brownfield L, Hrmova M, Wilson SM, Bacic A, Fincher GB (2006) Plant cell wall biosynthesis: genetic, biochemical and functional genomics approaches to the identification of key genes. Plant Biotechnol J 4:145-167

Fatehi F, Hosseinzadeh A, Alizadeh H, Brimavandi T, Struik PC (2012) The proteome response of salt-resistant and salt-sensitive barley. Mol Biol Rep 39:6387-6397

Fujiwara T, Mitsuya S, Miyake H, Hattori T, Takabe T (2010) Characterization of a novel glycinebetaine/proline transporter gene expressed in the mestome sheath and lateral root cap cells in barley. Planta 232:133-143

Fukuda A, Tanaka Y (2006) Effects of ABA, auxin and gibberellin on the expression of genes for vacuolar $\mathrm{H}^{+}$-inorganic pyrophosphatase, $\mathrm{H}^{+}$-ATPase subunit $\mathrm{A}$, and $\mathrm{Na}^{+} / \mathrm{H}^{+}$antiporter in barley. Plant Physiol Biochem 44:351-358

Galiana E, Bonnet P, Conrod S, Keller H, Panabieres F, Ponchet M, Poupet A, Ricci P (1997) RNase activity prevents the growth of a fungal pathogen in tobacco leaves and increases upon induction of systemic acquired resistance with elicitin. Plant Physiol 115:1557-1567

Gallardo K, Job C, Groot SPC, Puype M, Demol H, Vandekerckhove J, Job D (2002a) Importance of methionine biosynthesis for Arabidopsis seed germination and seedling growth. Physiol Plant 116:238-247 
Gallardo K, Job C, Groot SPC, Puype M, Demol H, Vandekerckhove J, Job D (2002b) Proteomics of Arabidopsis seed germination. A comparative study of wild type and gibberellin deficient seeds. Plant Physiol 129:823-837

Gill SS, Tuteja N (2010) Polyamines and abiotic stress tolerance in plants. Plant Signal Behav 51:26-33

Gimeno-Gilles C, Lelièvre E, Viau L, Malik-Ghulam M, Ricoult C, Niebel A, Leduc N, Limami AM (2009) ABA-mediated inhibition of germination Is related to the inhibition of genes encoding cell-wall biosynthetic and Architecture: modifying enzymes and structural proteins in medicago truncatula embryo axis. Mol Plant 2(1):108-119

Golldack D, Li C, Mohan H, Probst N (2014) Tolerance to drought and salt stress in plants: unraveling the signaling networks. Front Plant Sci 5:151

Gomez LD, Gilday A, Feil R, Lunn JE, Graham IA (2010) AtTPS1mediated trehalose 6-phosphate synthesis is essential for embryogenic and vegetative growth and responsiveness to $\mathrm{ABA}$ in germinating seeds and stomatal guard cells. Plant J 64:1-13

Görschen E, Dunaeva M, Hause B, Reeh I, Wasternack C, Parthier B (1995) Expression of the ribosome-inactivating protein JIP60 from barley in transgenic tobacco leads to an abnormal phenotype and alterations on the level of translation. Planta 202:470-478

Goubet F, Mohnen D (1999) Subcellular localization and topology of homogalacturonan methyltransferase in suspension-cultured $\mathrm{Ni}$ cotiana tabacum cells. Planta 209:112-117

Guan LM, Zhao J, Scandalios JG (2000) Cis-elements and transfactors that regulate expression of the maize Cat 1 antioxidant gene in response to ABA and osmotic stress: $\mathrm{H} 2 \mathrm{O} 2$ is the likely intermediary signaling molecule for the response. Plant $\mathrm{J}$ 22(2):87-95

Guo CWL, Devaiah SP, Narasimhan R, Pan X, Zhang Y, Zhang W, Wanga X (2012) Cytosolic glyceraldehyde-3-phosphate dehydrogenases interact with phospholipase $\mathrm{D} \delta$ to transduce hydrogen peroxide signals in the arabidopsis response to stress. Plant Cell 24:2200-2212

Habib H, Fazili KM (2007) Plant protease inhibitors: a defense strategy in plants. Biotechnol Mol Biol 2(3):068-085

Han SJ, Yoo YJ, Kang HS (1995) Characterization of a bifunctional cellulase and its structural gene. J Biol Chem 270(43):26012-26019

Hanson AD, Rivoal J, Paquet L, Gage DA (1994) Biosynthesis of 3-dimethylsulfoniopropionate in Wollastonia biflora (L.) DC. Evidence that $S$-methylmethionine is an intermediate. Plant Physiol 105:103-110

Hong B, Uknes SJ, T-hD Ho (1988) Cloning and characterization of cDNA encoding a mRNA rapidly-induced by ABA in barley aleurone layers. Plant Mol Biol 11:495-506

Howard J, Hyman AA (2003) Dynamics and mechanics of the microtubule plus end. Nature 422:753-758

Iqbal N, Umar S, Khan NA, Khan MIR (2014) A new perspective of phytohormones in salinity tolerance: regulation of proline metabolism. Environ Exp Bot 100:34-42

Jiang M, Zhang J (2001) Effect of abscisic acid on active oxygen species, antioxidative defence system and oxidative damage in leaves of maize seedlings. Plant Cell Physiol 42(11):1265-1273

Jiang M, Zhang J (2003) Water stress-induced abscisic acid accumulation triggers the increased generation of reactive oxygen species and up-regulates the activities of antioxidant enzymes in maize leaves. J Exp Bot 53:2401-2410

Jones H, Leigh RA, Tomos AD, Jones RGW (1987) The effect of abscisic acid on cell turgor pressures, solute content and growth of wheat roots. Planta 170(2):257-262

Jung HG, Deetz DA (1993) Cell wall lignification and degradability. In: Jung $\mathrm{HG}$ et al (eds) Forage cell wall structure and digestibility. ASA-CSSA-SSSA, Madison, pp 315-346
Kaur N, Reumann S, Hu J (2009) Peroxisome biogenesis and function. Arabidopsis Book 7:e0123

Keskin BC, Sarikaya AT, Yüksel B, Memon AR (2010) Abscisic acid regulated gene expression in bread wheat (Triticum aestivum L.). AJCS 4(8):617-625

Kornitzer D, Ciechanover A (2000) Modes of regulation of ubiquitinmediated protein degradation. J Cell Physiol 182:1-11

Kristensen BK, Bloch H, Rasmussen SK (1999) Barley coleoptile peroxidases: purification, molecular cloning and induction by pathogens. Plant Physiol 120:501-512

Krupková E, Immerzeel P, Pauly M, Schmülling T (2007) The TUMOROUS SHOOT DEVELOPMENT2 gene of Arabidopsis encoding a putative methyltransferase is required for cell adhesion and co-ordinated plant development. Plant J 50:735-750

Kumari S, Panjabi nee Sabharwal V, Kushwaha HR, Sopory SK, Singla-Pareek SL, Pareek A (2009) Transcriptome map for seedling stage specific salinity stress response indicates a specific set of genes as candidate for saline tolerance in Oryza sativa $\mathrm{L}$. Funct Integr Genom 9(1):109-123

Laemmli UK (1970) Cleavage of structural proteins during the assembly of the head of bacteriophage T4. Nature 227(5259):680-685

Lata C, Prasad M (2011) Role of DREBs in regulation of abiotic stress responses in plants. J Exp Bot 62(14):4731-4748

Laval J (1996) Role of DNA repair enzymes in the cellular resistance to oxidative stress. Pathol Biol (Paris) 44(1):14-24

Lee S-H, Lee K-W, Kim K-Y, Choi GJ, Yoon SH, Ji HC, Seo S, Lim YC, Ahsan N (2009) Identification of salt-stress induced differentially expressed genes in barley leaves using the annealing-control-primer-based GeneFishing technique. Afr J Biotechnol 8:1326-1331

Lehmann J, Atzorn R, Brückner C, Reinbothe S, Leopold J, Wasternack C, Parthier B (1995) Accumulation of jasmonate, abscisic acid, specific transcripts and proteins in osmotically stressed barley leaf segments. Planta 197:156-162

Leung J, Giraudat J (1998) Abscisic acid signal transduction. Annu Rev Plant Physiol Plant Mol Biol 49:199-222

Lindberg U, Karlsson R, Lassing I, Schutt CE, Hoglund AS (2008) The microfilament system and malignancy. Semin Cancer Biol 18:2-11

Lizarbe MA, Barrasa JI, Olmo N, Gavilanes F, Turnay J (2013) Annexin-phospholipid interactions. Functional implications. Int J Mol Sci 14:2652-2683

Lyzenga WJ, Stone SL (2012) Abiotic stress tolerance mediated by protein ubiquitination. J Exp Bot 63:599-616

Mahmood K (2011) Salinity tolerance in barley (Hordeum vulgare L.): effects of varying $\mathrm{NaCl}, \mathrm{K}^{+} / \mathrm{Na}^{+}$and $\mathrm{NaHCO}_{3}$ levels on cultivars differing in tolerance. Pak J Bot 43(3):1651-1654

Manjunath S, Sachs MM (1997) Molecular characterization and promoter analysis of the maize cytosolic glyceraldehyde 3-phosphate dehydrogenase gene family and its expression during anoxia. Plant Mol Biol 33:97-112

Miao Y, Lv D, Wang P, Wang XC, Chen J, Miao C, Song CP (2006) An Arabidopsis glutathione peroxidase functions as both a redox transducer and a scavenger in abscisic acid and drought stress responses. Plant Cell 18:2749-2766

Möller IM (2001) Plant mitochondria and oxidative stress: electron transport, NADPH turnover, and metabolism of reactive oxygen species. Annu Rev Plant Physiol Plant Mol Biol 52:561-591

Moons A, Prinsen E, Bauw G, Montagu MV (1997) Antagonistic effects of abscisic acid and jasmonates on salt stress-lnducible transcripts in rice roots. Plant Cell 9:2243-2259

Neuhoff V, Arold N, Taube D, Ehrhard W (1988) Improved staining in proteins in polyacrylamide gels including isoelectric focusing gels with clear background at nanogram sensitivity using 
Coomassie Brilliant Blue G-250 and R-250. Electrophoresis 9(6):255-262

Ogawa S, Mitsuya S (2012) $S$-methylmethionine is involved in the salinity tolerance of Arabidopsis thaliana plants at germination and early growth stages. Physiol Plant 144:13-19

Park MY, Kang J-y, Kim SY (2011) Overexpression of AtMYB52 confers ABA hypersensitivity and drought tolerance. Mol Cells 31(5):447-454

Passardi F, Longet D, Penel C, Dunand C (2004a) The class III peroxidase multigenic family in rice and its evolution in land plants. Phytochemistry $65: 1879-1893$

Passardi F, Penel C, Dunand C (2004b) Performing the paradoxical: how plant peroxidases modify the cell wall. Trends Plant Sci 9:534-540

Ranocha P, McNeil SD, Ziemak MJ, Li C, Tarczynski MC, Hanson AD (2001) The $S$-methylmethionine cycle in angiosperms: ubiquity, antiquity and activity. Plant J 25:575-584

Reinbothe S, Reinbothe C, Lehmann J, Becker W, Apel K, Parthier B (1994) JIP60, a methyl jasmonate-induced ribosome-inactivating protein involved in plant stress reactions. Proc Natl Acad Sci 91:7012-7016

Ridley AJ, Schwartz MA, Burridge K, Firtel RA, Ginsberg MH, Borisy G, Parsons JT, Horwitz AR (2003) Cell migration: integrating signals from front to back. Science 302:1704-1709

Romero S, Didry D, Larquet E, Boisset N, Pantaloni D, Carlier MF (2007) How ATP hydrolysis controls filament assembly from profilin-actin: implication for formin processivity. J Biol Chem 282:8435-8445

Roxas VP, Smith RK, Allen ER, Allen RD (1997) Overexpression of glutathione $S$-transferase/glutathione peroxidase enhances the growth of transgenic tobacco seedlings during stress. Nat Biotechnol 15:988-991

Roxas VP, Lodhi SA, Garrett DK, Mahan JR, Allen RD (2000) Stress tolerance in transgenic tobacco seedlings that overexpress glutathione $S$-transferase/glutathione peroxidase. Plant Cell Physiol 41(11):1229-1234

Rustgi S, Pollmann S, Buhr F, Springer A, Reinbothe C, von Wettstein D, Reinbothe S (2014) JIP60-mediated, jasmonateand senescence-induced molecular switch in translation toward stress and defense protein synthesis. PNAS 111(39):14181-14186

Saha P, Mukherjee A, Biswas AK (2015) Modulation of $\mathrm{NaCl}$ induced DNA damage and oxidative stress in mungbean by pretreatment with sublethal dose. Biol Plant 59:139-146

Sarmiento C, Wang W, Dovas A, Yamaguchi H, Sidan M, El-Sibai M, Desmarais V, Holman HA, Kitchen S, Backer JM, Alberts A, Condeelies J (2008) WASP family members and formin proteins coordinate regulation of cell protrusions in carcinoma cells. J Cell Biol 180:1245-1260

Sawasaki T, Nishihara M, Endo Y (2008) RIP and RALyase cleave the sarcin/ricin domain, a critical domain for ribosome function, during senescence of wheat coleoptiles. Biochem Biophys Res Commun 370:561-565

Schoonheim PJ, Sinnige MP, Casaretto JA, Veiga H, Bunney TD, Quatrano RS, de Boer AH (2007) 14-3-3 adaptor proteins are intermediates in ABA signal transduction during barley seed germination. Plant J 49:289-301

Shi H, Zhu J-K (2002) Regulation of expression of the vacuolar $\mathrm{Na}^{+} /$ $\mathrm{H}^{+}$antiporter gene AtNHX1 by salt stress and abscisic acid. Plant Mol Biol 50:543-550

Singh D, Laxmi A (2015) Transcriptional regulation of drought response: a tortuous network of transcriptional factors. Front Plant Sci 6:895

Sokol A, Kwiatkowska A, Jerzmanowski A, Prymakowska-Bosak M (2007) Up-regulation of stress-inducible genes in tobacco and Arabidopsis cells in response to abiotic stresses and ABA treatment correlates with dynamic changes in histone $\mathrm{H} 3$ and $\mathrm{H} 4$ modifications. Planta 227:245-254

Song A, Zhu X, Chen F, Gao H, Jiang J, Chen S (2014) A chrysanthemum heat shock protein confers tolerance to abiotic stress. Int J Mol Sci 15:5063-5078

Sripinyowanich S, Klomsakul P, Boonburapong B, Bangyeekhun T, Asami T, Gu H, Buaboocha T, Chadchawan S (2013) Exogenous ABA induces salt tolerance in indica rice (Oryza sativa L.): the role of $O s P 5 C S 1$ and $O s P 5 C R$ gene expression during salt stress. Environ Exp Bot 86:94-105

Szyjanowicz PM, McKinnon I, Taylor NG, Gardiner J, Jarvis MC, Turner SR (2004) The irregular xylem 2 mutant is an allele of korrigan that affects the secondary cell wall of Arabidopsis thaliana. Plant J 37:730-740

Szypulska E, Weidner S (2011) Importance of cytomatrix-bound polysomes to synthesis of lysine-containing proteins in triticale germs under ABA treatment. Acta Physiol Plant 33:1461-1465

Szypulska E, Weidner S (2016) ABA pretreatment can alter the distribution of polysomes in salt-stressed barley sprouts. Acta Mus Siles Sci Nat 65:257-261

Ticconi CA, Delatorre CA, Abel S (2001) Attenuation of phosphate starvation responses by phosphite in Arabidopsis. Plant Physiol 127:963-972

Tuteja N, Sopory SK (2008) Chemical signaling under abiotic stress environment in plants. Plant Signal Behav 3(8):525-536

Van Damme EJM, Hao Q, Barre A, Rouge P, Van Leuven F, Peumans WJ (2000) Major protein of resting rhizomes of Calystegia sepium (hedge bindweed) closely resembles plant RNases but has no enzymatic activity. Plant Physiol 122:433-445

Vannier MP, Thoiron B, Morvan C, Demarty M (1992) Localization of methyltransferase activities throughout the endomembrane system of flax (Linum usitatissimum L.) hypocotyls. Biochem J 286:863-868

Velasco R, Salamini F, Bartels D (1994) Dehydration and ABA increase mRNA levels and enzyme activity of cytosolic GAPDH in the resurrection plant Craterostigma plantagineum. Plant Mol Biol 26:541-546

Verslues PE, Kim YS, Zhu JK (2007) Altered ABA, proline and hydrogen peroxide in an Arabidopsis glutamate:glyoxylate aminotransferase mutant. Plant Mol Biol 64:205-217

Wang S, Kurepa J, Hashimoto T, Smalle JA (2011) Salt stressinduced disassembly of Arabidopsis cortical microtubule arrays involves $26 \mathrm{~S}$ proteasome-dependent degradation of SPIRAL1 C. Plant Cell 23:3412-3427

Weidner S, Każarnowicz M, Frączek E, Amarowicz R, Karamać M (2006) Exogenous abscisic acid increases stability of polysomes in embryos of triticale caryopses during germination. Acta Physiol Plant 28:627-634

Wibig T (2007) PCA data analysis. Chair of Theoretical Physics, Publishing House of University in Lodz, Lodz

Wilkinson S, Davies WJ (2010) Drought, ozone, ABA and ethylene: new insights from cell to plant to community. Plant Cell Environ 33:510-525

Wu L, Ge Q, Zhang J, Zhou J, Xu J (2013) Proteomic analysis of Cdresponsive proteins in Solanum torvum. Plant Mol Biol Rep 31:485-491

Xiong L, Schumaker KS, Zhu JK (2002) Cell signaling during cold, drought, and salt stress. Plant Cell 14:S165-S183

Yan N, Doelling JH, Falbel TG, Durski AM, Vierstra RD (2000) The ubiquitin-specific protease family from Arabidopsis. AtUBP1 and 2 are required for the resistance to the amino acid analog canavanine1. Plant Physiol 124:1828-1843

Yang W, Boss WF (1994) Regulation of phosphatidylinositol 4-kinase by the protein activator PIK-A49. J Biol Chem 269(5):3852-3857 
Yang SS, Zhai QH (2017) Cytosolic GAPDH: a key mediator in redox signal transduction in plants. Biol Plant. doi:10.1007/ s10535-017-0706-y

Ye Z-H, Droste DL (1996) Isolation and characterization of cDNAs encoding xylogenesis-associated and wounding-induced ribonucleases in Zinnia elegans. Plant Mol Biol 30:697-709

Yong JC, Barral JM, Ulrich Hartl F (2003) More than folding: localized functions of cytosolic chaperones. Trends Biochem Sci 28(10):541-547

Yu L (2008) Cell behavior and the role of profilin. Cell Biol 978-917155-677-6:1-53

Zhang X, Zhang L, Dong F, Gao J, Galbraith DW, Song CP (2001) Hydrogen peroxide is involved in abscisic acid-induced stomatal closure in Vicia faba. Plant Physiol 126(4):1438-1448

Zhang A, Jiang M, Zhang J, Ding H, Xu S, Hu X, Tan M (2007) Nitric oxide induced by hydrogen peroxide mediates abscisic acid-induced activation of the mitogen-activated protein kinase cascade involved in antioxidant defense in maize leaves. New Phytol 175(1):36-50
Zhang Y, Cheng Y, Guo J, Yang E, Liu C, Zheng X, Deng K, Zhou J (2014) Comparative transcriptome analysis to reveal genes involved in wheat hybrid necrosis. Int $\mathrm{J}$ Mol Sci 15:23332-23344

Zhao Y, Pan Z, Zhang Y, Qu X, Zhang Y, Yang Y, Jiang X, Huang S, Yuan M, Schumaker KS, Guo Y (2013) The actin-related Protein $2 / 3$ complex regulates mitochondrial-associated calcium signaling during salt stress in Arabidopsis. Plant Cell 25:4544-4559

Zheng J, Wang Y, He Y, Zhou J, Li Y, Liu Q, Xie X (2014) Overexpression of an $S$-like ribonuclease gene, OsRNS4, confers enhanced tolerance to high salinity and hyposensitivity to phytochrome-mediated light signals in rice. Plant Sci 214:99-105

Zhou X, Hua D, Chen Z, Zhou Z, Gong Z (2009) Elongator mediates ABA responses, oxidative stress resistance and anthocyanin biosynthesis in Arabidopsis. Plant J 60:79-90 